\title{
VARIATIONS ON A THEME-THE CONCEPT OF EQUAL EDUCATIONAL OPPORTUNITY AND PROGRAMMING DECISIONS UNDER THE EDUCATION FOR ALL HANDICAPPED CHILDREN ACT OF 1975
}

\author{
Judith Welch Wegner*
}

\section{INTRODUCTION}

[I]t is in the national interest that the Federal Government assist State and local efforts to provide programs to meet the educational needs of handicapped children in order to assure equal protection of the law. ${ }^{1}$

Congress' desire to assure that traditionally disadvantaged children receive equal educational opportunities has been a major theme running throughout much of the federal education legislation adopted in the last twenty years. ${ }^{2}$ The theme is an elusive and complex one. Scholars considering the scope of the Constitution's equal protection guarantee have disagreed sharply and repeatedly regarding which of several possible interpretations should be afforded the concept of "equal educational opportunity."3 Looking beyond the constitutional arena, educators and philoso-

Copyright $@ 1985$ by Law and Contemporary Problems

* Associate Professor of Law, University of North Carolina School of Law. Research for this article was supported by a grant from the North Carolina Law Center. The author wishes to express her appreciation to Kate Bartlett for her ever-thoughtful comments on the subject of this article and related matters, to Sally Sharp for her careful review of an earlier draft, and to Brian Caldwell for his invaluable research assistance. Insights gained by the author through discussions with staff of the Office of Special Education and Office of Civil Rights during her tenure as Special Assistant to United States Secretary of Education Shirley M. Hufstedler also contributed immeasurably to the work on this article. The views here presented are, of course, those of the author.

1. 20 U.S.C. $\$ 1400$ (b)(9) (1982). Education for All Handicapped Children Act of 1975, Pub. L. No. $94-142, \S 3(\mathrm{~b})(9), 89$ Stat. $773,774$.

2. See, e.g., S. ReP. No. 146, 89th Cong., 1 st Sess., reprinted in 1965 U.S. Code Cong. \& Ad. News 1446, 1449-50 (discussing Elementary and Secondary Education Act of 1965, Pub. L. No. 89-10, 79 Stat. 27, designed to provide full opportunity for a high quality program of instruction in basic skills so as to overcome effects of poverty and to provide a "basic floor" of services for all adults and children in the United States); see generally Levin, Equal Educational Opportunity for Special Pupil Populations and the Federal Role, 85 W. VA. L. REv. 159 (1983); Tolette, The Propriety of the Federal Role in Expanding Equal Educational Opportunity, 52 Harv. Educ. Rev. 431 (1982).

3. Important early analyses of this question include Kurland, Equal Educational Opportunity: The Limits of Constitutional Jurisprudence Undefined, 35 U. CHI. L. Rev. 583 (1968); Schoettle, The Equal Protection Clause in Public Education, 71 CoLum. L. REv. 1355 (1971); Yudof, Equal Educational Opportunity and the Courts, 51 TEx. L. Rev. 411 (1973). More recent scholarship has continued to examine competing definitions of constitutional equal protection. See, e.g., Baker, Outcome Equality or Equality of Respect: 
phers have recognized that the concept of equal opportunity is inherently a protean one which may take different shapes depending not only upon the context in which it is applied, but also upon which of a number of possible objectives are sought to be achieved in a particular context. ${ }^{4}$

Lawmakers seeking to embody the concept of equal educational opportunity in statutory form may hope, through legislative specificity, to avoid some of the uncertainty of interpretation associated with the Constitution's terse equal protection guarantee. The development of a detailed statutory scheme necessitates a rather intricate statement of the equal educational opportunity theme, however, and such intricacy may well compound rather than simplify the problem of interpretation. Such a scheme may include numerous points at which imprecise or ambiguous guidance is provided concerning which of several subtly different conceptions of equal educational opportunity should control. Problems of interpretation may also arise due to internal tensions created when this highly nuanced concept is given different form in several of a statute's myriad provisions.

The Education for All Handicapped Children Act of 1975 (EAHCA or the Act $)^{5}$ illustrates the interpretive problems that have arisen when the already elusive concept of equal educational opportunity is given more complex statutory form. Congress' concern with the limited educational opportunities available to handicapped children spurred the enactment of this measure in

The Substantive Content of Equal Protection, 131 U. PA. L. Rev. 933 (1983); Levin, The Courts, Congress, and Educational Adequacy: The Equal Protection Predicament, 39 Mo. L. Rev. 187 (1979).

4. See, e.g., D. RaE, Equalitries (1981) (describing more than 108 distinct interpretations of equality involving numerous variables including whether the subject of equality is individualregarding, segmental, or block-regarding; whether means-regarding or prospect-regarding equal opportunity is involved; whether the equality is lot-regarding or person-regarding; and whether equality is relative or absolute); A. WISE, Rich Schools, Poor Schools 143-59 (1967) (outlining nine definitions of equal educational opportunity, including a "negative definition" (child's opportunity does not depend on parents' economic circumstances or location within state); "full opportunity" definition (schools must give child every conceivable assistance in developing his abilities); "foundation" definition (schools provide satisfactory minimum educational offering in form of minimum outlay on each pupil); "minimum attainment" definition (schools must allocate adequate resources to allow each student to reach a specified level of achievement); "leveling" definition (schools allocate resources in inverse proportion to students' abilities); "competition" definition (schools allocate resources in direct proportion to students' abilities); "equal dollars per pupil" definition (schools allocate same level of resources to each student); "maximum variance ratio" definition (schools allocate resources to pupils at a level which falls within a set percentage of deviation from expenditures of other school districts); "classification" definition (schools provide students with certain characteristics the same program of educational services which are provided to students with corresponding characteristics elsewhere in the state)); Joseph, Some Ways of Thinking About Equality of Opportunity, 33 Western Pol. Q. 393 (1980) (distinguishing between equality of result and formal, compensatory, competitive, and developmental types of equality of opportunity); Coleman, The Concept of Equality of Educational Opportunity, 38 Harv. Educ. Rev. 7, 16-17 (1968), reprinted in EQUal EduCATIONAL OPPORTUNITY 9 (1969) (discussing types of inequality including inequality with respect to community's tangible and intangible inputs into schools, with respect to racial composition of school populations, with respect to consequences of schools for individuals with equal backgrounds and abilities, with respect to consequences for those with unequal backgrounds and abilities, and with respect to relative intensities of school and home influences).

5. Pub. L. No. 94-142, 89 Stat. 773 (codified as amended at 20 U.S.C. $\S \S 1400-01,1405-06$, $1411-20,1453,1232(1982))$. 
1975.6 It responded to a well-documented pattern of unequal opportunity, which has resulted in the outright exclusion of handicapped children from schools in many cases and their placement in poorly supported, ineffective special classes in many others. ${ }^{7}$ Congressional action was triggered by a rising tide of constitutional litigation such as Pennsylvania Association for Retarded Children (PARC) v. Pennsylvania ${ }^{8}$ and Mills v. Board of Education. ${ }^{9}$ Both

6. Congress had originally authorized federal financial assistance for special education in 1966 . Elementary and Secondary Education Amendments of 1966, Pub. L. No. 89-750, § 161, 80 Stat. 1191, 1204-08 (repealed by Pub. L. No. 91-230 § 622, 84 Stat. 188; current version in scattered sections in 20 U.S.C. $\$ \S 1400-1461$ ) (adding new Title VI to Elementary and Secondary Education Act of 1965, Pub. L. No. 89-10, 79 Stat. 27). Four years later, the Education of the Handicapped Act was enacted. Pub. L. No. 91-230, Title VI, §§ 601-622, 84 Stat. 175-88 (1970) (codified in scattered sections in 20 U.S.C. $\S \S 1400-1461$ (1982)). Part B of that Act authorized grants to the states and outlying areas to assist them in initiating, expanding, and improving programs for the education of the handicapped. Id. at $\S 611$ (a); 84 Stat. 178, (amended by Pub. L. No. 94-142, $\S 5$, 89 Stat. 773, 776 , current version at 20 U.S.C. \$ 1411). Amendments to the 1970 legislation were adopted in 1974 , as a first step in modifying the federal funding formula subsequently revised by the EAHCA. See Education of the Handicapped Amendments of 1974, Pub. L. No. 93-380, §§ 611-621, 88 Stat. $579-85$ (codified at 20 U.S.C. $\$ \S 1401-1461$ (1982)). The 1974 amendments also contained the seeds of several important substantive provisions now found in the EAHCA. See Comment, The Least Restrictive Environment Section of the Education for All Handicapped Children Act of 1975: A Legislative History and An Analysis, 13 GonZaGa L. Rev. 717, 762-67 (1978).

The 1975 legislation was adopted following extensive hearings. See Education for All Handicapped Children, 1975 Hearings Before the Subcomm. on the Handicapped of the Senate Comm. on Labor and Public Welfare on S. 6, 94th Cong., 1st Sess. (1975); Education for All Handicapped Children, 1973-74, Parts 1-3; Hearings Before the Subcomm. on the Handicapped of the Senate Comm. on Labor and Public Welfare on S. 6, 93rd Cong., 1st \& 2d Sess. (1973-74); Financial Assistance for Improved Educational Services for Handicapped Children: Hearings Before the Select Subcomm. on Education of the House Comm. on Education and Labor on H.R. 70, 93rd Cong., 2d Sess. (1974).

7. See generally Lazerson, The Origins of Special Education, in Special Education Policies 15 (J. Chambers \& W. Hartman eds. 1983); Burgdorf \& Burgdorf, A History of Unequal Treatment: The Qualifcations of Handicapped Persons as a "Suspect Class" under the Equal Protection Clause, 15 SANTA Cl.ara L. Rev. 855, 868-83, 899-910 (1975).

8. 343 F. Supp. 279 (E.D. Pa. 1972); see also 334 F. Supp. 1257 (E.D. Pa. 1971) (earlier consent decree). In PARC, mentally retarded residents of the Pennsylvania state institution at Pennhurst alleged that they had been improperly denied any meaningful education. Since scientific evidence had established that all children, including developmentally disabled children, have the capacity to learn, plaintiffs asserted that no rational basis existed to justify the state's failure to provide suitable educational opportunities, and that the state's action therefore violated the equal protection clause of the federal constitution. Moreover, plaintiffs claimed that the state's exclusion of a vague category of "uneducable" children from such opportunities, without the benefit of notice or a hearing, violated the due process clause. The state agreed to end proceedings pursuant to a negotiated consent decree. In its order approving that decree, the three-judge federal court reserved its judgment on the merits, but stated that plaintiffs had stated a "colorable constitutional claim." 343 F. Supp. at 288 n.19.

The PARC decision has been the subject of extensive scholarly commentary. See, e.g., Haggerty \& Sacks, Education of the Handicapped: Towards a Definition of an Appropriate Education, 50 TEMP. L.Q. 961, 966-75 (1977); Kirp, Buss \& Kuriloff, Legal Reform of Special Education: Empirical Studies and Procedural Proposals, 62 Calif. L. Rev. 40, 58-82 (1974); Neal \& Kirp, The Allure of Legalization Reconsidered: The Case of Special Education, Law \& Contemp. Probs., Winter 1985, at 63, 69-70.

9. 348 F. Supp. 866 (D.D.C. 1972). Mills was brought on behalf of mentally, physically, and emotionally disturbed children who had been excluded from educational opportunities in the District of Columbia schools. Mills squarely held that exclusion of handicapped children from public education violated the Fifth Amendment. Id. at 875 . Mills added to the PARC reasoning in two noteworthy respects. First, the Mills court rejected the District's putative cost defense, holding that the problem of insufficient funds faced by the school board could not be permitted to result in an outright denial of educational opportunity to handicapped children, nor could the inadequacies of the school system bear more heavily on the exceptional or handicapped child than on his nonhandicapped counter- 
cases had recognized that handicapped children were entitled to participate in the nation's schools by receiving educational services appropriate to their special needs. The resulting legislation sought, to a significant extent, to incorporate this developing constitutional doctrine into federal law applicable throughout the fifty states. ${ }^{10}$ Congress went further, however, elaborating upon the already intricate equal educational opportunity theme by introducing novel and important statutory variations. ${ }^{11}$

This article explores the equal educational opportunity theme as it is embodied in the EAHCA's educational programming requirements. It will focus on three key questions. First, it will consider the level and extent of services which must be provided under the Act to address handicapped children's educational needs. Specifically, it will discuss the courts' efforts to determine whether the mix of services to be afforded must guarantee a handicapped child only minimal educational opportunity, opportunity equivalent to that provided his nonhandicapped peers, or some more optimal opportunity. Second, the article will consider which of a handicapped child's many needs must be met at public expense pursuant to the EAHCA. To this end, it will examine the problems encountered when parents seek services which simultaneously address both a child's educational needs and his emotional and custodial needs, services which have traditionally been regarded as noneducational in nature and thus beyond the range of schools' responsibilities to nonhandicapped children. Third, the article will explore the special problems which

parts. Id. at 876. Second, the court issued an extensive remedial order which foreshadowed many of the substantive provisions included in the EAHCA. Among these were the requirements that all handicapped children be served, that each child be provided an "appropriate" education suitable to his individual needs, that children be placed in the most normal setting in which they could function effectively, and that they and their parents be afforded notice and an opportunity for a hearing before potentially adverse changes in placement were made. Id. at 878-83.

For more extensive discussion of the Mills decision, see generally those secondary sources which address the $P A R C$ case, cited supra note 8.

For a further discussion by early proponents of handicapped children's constitutional right to equal educational opportunity, see also Dimond, The Constitutional Right to Education: The Quiet Revolution, 24 Hastings L.J. 1087 (1973); Handel, The Role of the Advocate in Securing the Handicapped Child's Right to an Effective Minimal Education, 36 Oнiо Sт. L.J. 349 (1975); Herr, Retarded Children and the Law: Enforcing the Constitutional Rights of the Mentally Retarded, 23 Syracuse L. Rev. 995 (1972).

10. The legislative history of the EAHCA is replete with references to PARC and Mills. See, e.g., S. ReP. No. 168, 94th Cong., 1st Sess. 6, reprinted in 1975 U.S. Code Cong. \& Ad. News 1425, 1430 (discussing PARC and Mills decisions); id. at 9, reprinted in U.S. Code Cong. \& AD. News at 1433 (stating that "over the past few years, parents of handicapped children have begun to recognize that their children are being denied services which are guaranteed under the Constitution. It should not be necessary for parents throughout the country to continue utilizing the courts to assure themselves a remedy."); H.R. REP. No. 322, 94th Cong., 1st Sess. 3-4 (1975) (discussing PARC, Mills and various state court decisions).

11. For commentary which provides a useful summary of the Act's principal provisions, see generally L. Rothstein, Rights of Physically Handicapped Persons 25-48 (1984); Blakely, Judicial and Legislative Attitudes Toward the Right to an Equal Education for the Handicapped, 40 OHIo Sr. L.J. 603, 615 33 (1979); Colley, The Education for All Handicapped Children Act (EHA): A Statutory and Legal Analysis, 10 J. LAw \& Educ. 137 (1981); Krass, The Right to Public Education for Handicapped Children: A Primer for the New Advocate, 1976 U. ILL. L.F. 1016, 1063-77; Stark, Tragic Choices in Special Education: The Effect of Scarce Resources on the Implementation of Pub. L. No. 94-142, 14 ConN. L. REv. 477 (1982). For an excellent review of procedural problems raised in litigation under the Act, see Hyatt, Litigating the Rights of Handicapped Children to an Appropriate Education: Procedures and Remedies, 29 UCLA L. REv. 1 (1981). 
have arisen in determining whether noninstructional medical services, traditionally unavailable to nonhandicapped students, must be provided by school systems as a result of this federal legislation. In particular, it will focus on the recent debate regarding the availability of clean intermittent catheterization and psychotherapy services, which some have urged should be regarded as nondiagnostic, nonevaluative medical services that need not be provided under the EAHCA.

The article will argue that these controversies can be more fully understood by examining the equal educational opportunity theme that unites them. It will demonstrate that the courts which have been asked to address each of the three questions just described have done so in ways that reflect underlying uncertainty as to whether and how the concept of equal educational opportunity bears upon their resolution of various programming disputes. It will urge that recognizing the important role of equal educational opportunity as a source of uncertainty, and identifying and evaluating the competing interpretations of that concept that have emerged to date in the three contexts of interest here, provides helpful insight into the substantive requirements of the EAHCA.

Parts II and III will consider the level and extent of services required to be provided under the EAHCA. Reserving the more specific questions discussed in subsequent portions of this paper, part II will focus on pertinent legislative history and upon early cases interpreting the Act's requirement that all handicapped children be afforded a "free appropriate public education" (FAPE). Part III will examine the United States Supreme Court's landmark decision in Board of Education v. Rowley ${ }^{12}$ and conclude that the Court's interpretation of the Act's FAPE requirement as guaranteeing a minimally equal level of educational opportunity to handicapped children is a legitimate and necessary reading of the Act.

Part IV will discuss judicial efforts to delineate the scope or range of handicapped children's needs which must be addressed by the schools pursuant to the EAHCA. It will suggest that novel questions are posed by the juxtaposition of this statutory scheme with the traditional approach to meeting the educational, but not noneducational, needs of nonhandicapped children in the nation's schools. It will argue that the EAHCA supplants this traditional scheme by embodying an inclusionary, rather than exclusionary, approach to defining educational needs, that is, one that requires that services be provided where needed for educational purposes, even if noneducational needs are at the same time addressed. It will also suggest that courts should go farther and abandon the classic dichotomy between educational and noneducational needs, instead recognizing that all needs that directly or indirectly affect a child's educational performance must be addressed pursuant to the EAHCA, subject, of course, to the substantial limitations on the level and extent of services, and the types of services required, described in parts II, III and V.

12. 458 U.S. 176 (1982). 
Part V will consider whether certain services, reasonably described as medical in nature, must be provided by school districts under the Act. It will argue that textual references to medical services clearly limit districts' obligations in this regard, but that it is less certain whether the EAHCA's nonevaluative, nondiagnostic medical services exception is partial or complete. It will urge that this provision can reasonably be interpreted as a partial exception designed to limit schools' responsibilities in view of the particularly expansive definitions of equal educational opportunity possibly or actually embodied elsewhere in the Act. It will argue that this approach is consistent both with the Supreme Court's determination, in Irving Independent School District $v$. Tatro, ${ }^{13}$ that clean intermittent catheterization is a related service, and with the judgment of a number of lower courts that intensive psychological services, in the form of psychotherapy, may be required in certain cases.

II

\section{Level and Extent of Services Prior to Rowley}

Disputes often arise between parents and school officials regarding the level and extent of educational services to be provided a particular child. ${ }^{14}$ Disagreement concerning the level and extent of educational programming is most commonly voiced in practical terms: what pupil-teacher ratio must be employed in a class for emotionally disturbed students; ${ }^{15}$ how many months of instruction need be provided; 16 must a teacher's aide be retained to accompany a handicapped child to mainstream classes; ${ }^{17}$ and what method of instruction should be adopted for mentally retarded students' basic life-skills instruction. ${ }^{18}$

13. 104 S. Ct. 3371 (1984).

14. See generally Kirst \& Bertken, Due Process Hearings in Special Education: Some Early Findings From California, in Special Education Policies 136 (J. Chambers \& W. Hartman eds. 1983) (reporting that in California administrative hearings studied, more than 22 percent of cases involved requests for related services or an extended school year, while more than 70 percent of cases involved demands for services allegedly available only through private day programs which traditionally have provided more intensive services than those available through many public schools. Id. at 142-43.); Kuriloff, Is Justice Served by Due Process?: Affecting the Outcome of Special Education Hearings in Pennsylvania, Law \& Contemp. Probs., Winter 1985, at 89.

15. See Colin K. v. Schmidt, 536 F. Supp. 1375, 1386-87 (D.R.I. 1982), affd, 715 F.2d 1 (1st Cir. 1983).

16. E.g., Crawford v. Pittman, 708 F.2d 1028 (5th Cir. 1983); Armstrong v. Kline, 476 F. Supp. 583 (E.D. Pa. 1979), remanded sub nom. Battle v. Pennsylvania, 629 F.2d 269 (3d Cir. 1980), cert. denied, 452 U.S. 968 (1981); Yaris v. Special School Dist., 558 F. Supp. 545 (E.D. Mo. 1983), affd, 728 F.2d 1055 (8th Cir. 1984); Stacy G. v. Pasadena Indep. School Dist., 547 F. Supp. 61, $79-80$ (S.D. Tex. 1982); Georgia Ass'n of Retarded Citizens v. McDaniel, 511 F. Supp. 1263 (N.D. Ga. 1981), affd, 716 F.2d 1565 (11th Cir. 1983), vacated, 104 S. Ct. 3581 (1984), aff d as modified, 1984-85 Educ. Handicapped L. Rep. (CRR) (11th Cir. 1984) (on EAHCA grounds only); Bales v. Clarke, 523 F. Supp. 1366 (E.D. Va. 1981); Anderson v. Thompson, 495 F. Supp. 1256, 1265-67 (E.D. Wis. 1980), affd, 658 F.2d 1205 (7th Cir. 1981); Birmingham \& Lamphere School Dists. v. Superintendent of Pub. Instruction, 120 Mich. App. 465, 328 N.W.2d 59 (1982).

17. See In $r e$ Brookfield Pub. Schools, 1982-83 Educ. Handicapped L. ReP. (CRR) 504:166 (Mass. SEA 1982).

18. See In re Marin County Office of Educ., 1982-83 Educ. HandiCAPPEd L. ReP. (CRR) 504:162 (Cal. SEA 1982). 
These concrete problems mask a more deep-seated theoretical conflict, however. Many school districts believe that their obligation to handicapped children is a relatively limited one which requires them to provide such children with sufficient educational programming to allow the children to derive "some benefit" from their educational experience. In those districts' view, this is all they are obliged to provide to any student, all they can measure, and all they can afford. In more theoretical terms, this "some benefit" standard might well be characterized as a first derivative of the "minimum attainment" definition of equal educational opportunity recognized by school finance theorists. ${ }^{19}$ Under that definition, resources are to be allocated so that every student reaches a specified level of achievement. ${ }^{20}$ In contrast, the "some benefit" approach, of interest here, would assure students of receiving resources needed to make some incremental progress toward their educational goals, without guaranteeing the means necessary to the actual achievement of those goals.

Parents have often espoused competing views. They tend to reject the "some benefit" standard, which assures handicapped children a minimal opportunity, in instances in which other children receive services designed to facilitate their attaining a more than minimal level of achievement. Parents have generally preferred either of two alternative approaches that reflect a more broadly conceived interpretation of equal educational opportunity.

On the one hand, parents may urge that an "equivalent opportunity" be provided their handicapped child. Thus, if a nonhandicapped child receives programming that gives him a good chance to achieve appropriate educational goals, a handicapped child should likewise be entitled to a good education, taking his handicapping condition into account. In theoretical terms, this "equivalent opportunity" standard perhaps most closely resembles another vintage definition of equal educational opportunity proposed in the aftermath of Brown v. Board of Education: ${ }^{21}$ the provision of equal tangible and intangible educational inputs for all school children. ${ }^{22}$ The "equivalent opportunity" standard described here differs from this vintage definition in certain respects, however. The "equivalent opportunity" standard entails comparison of tangible services and facilities, such as pupil-teacher ratios, rather than intangible factors, such as teacher morale. Such tangible factors may, however, defy comparison in much the same way that intangibles do, in view of the inherent differences in expenditures, facilities, design, and other program characteristics that are associated with regular and special education programs of equivalent quality. Moreover, a determination of "equivalent opportunity" for present purposes seems to envision comparison not just between programs for handicapped and nonhandicapped children generally, but also between individual handicapped children and their handicapped or

19. The minimum attainment definition is discussed in A. WISE, supra note 4 , at 151 .

20. Id.

21. 347 U.S. $483 .(1954)$.

22. Coleman, supra note 4 , at 17. 
nonhandicapped peers. The "equivalent opportunity" standard therefore requires even more complex comparative analysis than would be contemplated under an application of the vintage standard to ensure equality of opportunity between and among schools or school districts.

Alternatively, parents may argue that schools should provide a handicapped child with an "equalized" educational opportunity, by affording him whatever services are needed to minimize the effects of his handicapping condition, thereby allowing him to benefit as nearly as possible from the same educational opportunities that are available to his nonhandicapped peers. This argument may be particularly appealing to parents of physically impaired students who could be fully integrated into mainstream classes if adequate means of translation were provided or physical barriers overcome. Viewed from a more theoretical perspective, the "equalized educational opportunity" standard represents a blend of two traditional definitions of equal educational opportunity. It resembles the "leveling" definition of that concept, which asserts that resources should be allocated in inverse proportion to students' abilities, ${ }^{23}$ for it contemplates that handicapped children would be provided with whatever services are necessary to allow them to compete as nearly as possible on an equal footing with their nonhandicapped peers. It also resembles the "full opportunity" definition of "equal educational opportunity," which assumes that all students will be given adequate resources to allow them to develop their individual abilities to the limit. ${ }^{24}$ Under the "equalized educational opportunity" standard, however, full opportunity would be provided only to handicapped children, and only where, in the absence of full opportunity, those children would be unable to profit from generally available educational opportunities to the same extent as their nonhandicapped peers.

Congress and the courts, no less than schools and parents, have been troubled by such deep-seated conflicts, reflecting a fundamental uncertainty regarding the interpretation of the concept of equal educational opportunity as it applies to the level and extent of educational programming under the Act. Section A of this part discusses pertinent portions of the EAHCA's statutory text and legislative history. Section B reviews early judicial decisions regarding the level and extent of services required. The Supreme Court's efforts to resolve this uncertainty are the subject of part III.

\section{A. Congressional Guidance}

The EAHCA's substantive mandate is a deceptively simple one. In order to qualify for categorical federal assistance, states and subsidiary local educational agencies must agree to ensure that handicapped children ${ }^{25}$ within their

23. A. WISE, supra note 4 , at 152-53.

24. Id. at $148-49$.

25. "Handicapped children" protected by the Act include "mentally retarded, hard of hearing, deaf, speech impaired, visually handicapped, seriously emotionally disturbed, orthopedically impaired, or other health impaired children, or children with specific learning disabilities, who by reason thereof require special education and related services." 20 U.S.C. \$1401(1) (1982). Regulations defining each of the listed handicaps appear at 34 C.F.R. $\$ 300.5$ (1984). 
jurisdictions receive a "free appropriate public education."26 A "free appropriate public education" is, in turn, composed of two programmatic components: "special education" and "related services.",27 The free appropriate public education required to be provided any individual child is determined through an innovative consultation process. After a child has been identified as handicapped, he is evaluated and a meeting of parents, teachers, other professionals, and perhaps the child himself is convened to develop the child's own "individualized education program" (IEP). ${ }^{28}$ The IEP includes a statement of the child's present levels of educational performance, his annual goals and short-term instructional objectives, the educational services he is to receive and the setting in which they are to be provided, the initiation date and duration of those services, and the criteria and evaluation procedures to be used in determining whether those instructional services are being achieved. ${ }^{29}$ Parents who object to a proposed IEP may invoke their due process rights to an administrative appeal. ${ }^{30}$ Either parents or school officials may then pursue an additional appeal in state or federal court. ${ }^{31}$

For present purposes, the critical textual provisions are those which define "special education" and "related services," for it is in these provisions that Congress endeavored to establish the broad contours of the educational programming available under the Act. "Special education" is defined as "specially designed instruction, at no cost to parents or guardians, to meet the unique needs of a handicapped child, including classroom instruction, instruction in physical education, home instruction, and instruction in hospi-

26. See 20 U.S.C. $\$ 1412(2)$ (B) (1982) ("In order to qualify for assistance under this part . . . a State shall demonstrate . . . that . . . (1) [it] has in effect a policy that assures all handicapped children the right to free appropriate public education, (2) [it has developed a plan to assure that] (B) a free appropriate public education will be available for all handicapped children between the ages of 3 and 18 within the State. . . ."); id. $\$ 1414($ a) ("A local educational agency . . . which desires to receive payments . . . for any fiscal year shall submit an application . . . [which] shall . . . (1)(C) establish a goal of providing full educational opportunities to all handicapped children, including ... (ii) the provision of, and the establishment of priorities for providing, a free appropriate public education...").

27. See id. $\$ 1401(18)$ (defining "free appropriate public education" as "special education and related services which (A) have been provided at public expense under public supervision and direction, and without charge, (B) meet the standards of the State educational agency, (C) include an appropriate preschool, elementary, or secondary education in the State involved, and (D) are provided in conformity with the individualized education program required under section $1414(\mathrm{a})(5)$ of this title").

28. See id. §1401(19).

29. For a detailed discussion of specific problems likely to arise in the development of a child's IEP, see 34 C.F.R. $\S 300$ App. C (1984) (notice of interpretation of federal regulations governing development of IEP's); Id. $\$ \S 300.341-.349$.

30. See 20 U.S.C. $\$ 1415$ (b) (1982) (describing procedural safeguards, including right of parents or a guardian to examine relevant records, to obtain independent educational evaluation, to receive written prior notice of proposed changes in evaluation, programming, or placement, and to file complaint triggering impartial administrative hearing by state educational agency); 34 C.F.R. $§ 300.500$ .514 (1984) (governing due process rights).

31. See id. $\$ 1415(\mathrm{e})(2)$ (describing right of party aggrieved by findings and decision of impartial hearing officer to bring civil action in state court of competent jurisdiction or in federal district court, and requiring court to "receive the records of the administrative proceedings, [to] hear additional evidence at the request of a party and, basing its decision on the preponderance of the evidence, [to] grant such relief as [it] determines is appropriate"). 
tals and institutions." 32 "Related services," in turn, include "such developmental, corrective, and other supportive services . . . as may be required to assist a handicapped child to benefit from special education . . . ."33

This statutory language is, unfortunately, ambiguous. Although the definition of "special education" indicates that instruction is required "to meet the unique needs" of each handicapped child, it does not clearly specify whether "meeting" such needs entails merely addressing those needs, fully satisfying those needs, or something in between. Similarly, the key term "benefit," included in the "related services" definition, is susceptible to several interpretations. The benefit provided might take the form of minimal, incremental progress toward the child's educational objectives, progress toward those objectives to the same extent as the child's nonhandicapped peers, or enjoyment of the maximum benefits conceivable. Thus, the statutory language is arguably amenable to any of the three interpretations of equal educational opportunity-some benefit, equivalent benefit, or equalized benefit-introduced above. ${ }^{34}$ Other statutory provisions provide little additional insight on this point. ${ }^{35}$

The statute's legislative history is no more enlightening. Committee reports discussing the FAPE requirement and pertinent definitions do little more than restate the statutory text. ${ }^{36}$ General statements of a desire to ensure that handicapped children receive "equal educational opportunities"

32. Id. § 1401(16).

33. Id. $\$ 1401(17)$.

34. See supra text accompanying notes 19-24.

35. The EAHCA also contains several references to Congress' desire that handicapped children be provided with "full equality of educational opportunity" or "full educational opportunity." See 20 U.S.C. $\S 1400(\mathrm{~b})(3)(1982)$ ("Congress finds that . . . more than half of the handicapped children in the United States do not receive appropriate educational services which would enable them to have full equality of opportunity"); id. \$1412(2)(A)(i) (State eligibility conditioned upon development of plan with policies and procedures which the State will undertake to assure that there is established "a goal of providing full educational opportunity to all handicapped children"); id. $\$ 1414(\mathrm{a})(1)(\mathrm{C})$ (local educational agency desiring to receive funds under EAHCA must submit application to state educational agency which "establish[es] a goal of providing full educational opportunites to all handicapped children").

Arguably, this language suggests that Congress intended to require that the needs of handicapped children must be met as fully as possible, that is, that they be afforded an "equalized" educational opportunity. As this article demonstrates, however, the concept of equal educational opportunity bears on a number of aspects of the statutory scheme, and a similar interpretation of this concept need not have been intended in each of these differing contexts. Federal regulators appear to have recognized as much, for they carefully distinguished the terms "free appropriate public education" and "full educational opportunity goal" in commentary to 1977 EAHCA regulations. In their view the phrase "full educational opportunity goal" is broader in scope than "FAPE" because it covers children aged birth through 21 , includes a planning as well as programming function, allows local educational agencies to set their own timetables for meeting that goal, and calls for the provision of additional facilities, personnel, and services to further enrich a handicapped child's educational opportunity beyond that mandated under the FAPE requirement. 42 Fed. Reg. 42,506 (1977). The inclusion of references to "full educational opportunity" elsewhere in the statuce is thus of limited assistance in interpreting the critical FAPE standard and related definitions.

36. See, e.g., S. Rep. No. 168, 94th Cong., Ist Sess. 10, reprinted in 1975 U.S. Code Cong. \& AD. News 1425, 1434; H.R. Rep. No. 332, 94th Cong., 1st Sess. 18 (1975); S. ReP. No. 455, 94th Cong., 1st Sess. 29-30 (1975). 
are scattered throughout reports, hearings, and floor debates. ${ }^{37}$ More specific comments hint at a wide range of underlying views. For example, some proponents suggested that the legislation was designed to require school systems to provide equal educational opportunities which conformed to constitutional mandates.38 Others desired that "equivalent"39 or "full"40 educational opportunities be afforded. In sum, Congress provided only limited guidance concerning the level and extent of services to be required, merely suggesting, in a general way, that some sort of equality-based standard might reasonably be employed.

\section{B. Early Judicial Response}

Faced with limited legislative and administrative 1 guidance, the courts were initially left to their own devices to clarify the substantive standard to be used in assessing the sufficiency of educational programming under the EAHCA. Perhaps not surprisingly, early court decisions in many instances gave lip service to some sort of equality-based standard, but split sharply over the precise type of equality they believed the statute guaranteed.

The greatest number of cases spoke generally of Congress' desire to ensure "equal educational opportunity," but adopted a restrictive "some benefit" test in order to determine whether an "appropriate" education had been provided. ${ }^{42}$ The test was variously stated and variously applied. At times, the courts spoke of the existence or absence of regression or other harm. ${ }^{43}$ In some instances, this standard seems to have been applied because evidence of

37. See, e.g., S. ReP. No. 168, 94th Cong., lst Sess. 9, reprinted in 1975 U.S. Code Cong. \& AD. News 1425, 1433; 121 Cong. Rec. 19,483 (1975) (remarks of Sen. Randolph); id. at 19,504 (Sen. Humphrey); $i d$. at 19,505 (Sen. Beall); id. at 23,704 (Rep. Brademas); id. at 25,540 (Rep. Grassley); id. at 37,030-31 (Rep. Mink); id. at 37,412 (Sen. Taft); id. at 37,413 (Sen. Williams); id. at 37,418-19 (Sen. Cranston); id. at 37,419-20 (Sen. Beall); Education for All Handicapped Children 1973-74 Hearings Before the Subcomm. on the Handicapped of the Senate Comm. on Labor and Public Welfare on S. 6, 93d Cong., 1st Sess. (1973), part 1, at 31 (Sen. Williams).

38. 121 Cong. Rec. 37,413 (1975) (remarks of Sen. Williams); see also supra note 10 (discussing portions of the legislative history that reflect a desire to embody constitutional principles of early cases into statutory form).

39. 121 Cong. ReC. 19,483 (1975) (remarks of Sen. Stafford).

40. See, e.g., 121 Conc. Rec. 19,482-83 (1975) (remarks of Sen. Randolph); id. at 23,703-05 (Rep. Brademas); id. at 25,538 (Rep. Cornell); id. at 37,025 (Rep. Perkins); H.R. ReP. No. 332, 94th Cong., lst Sess. 11 (1975); see also id. at 13 (handicapped child requires tailored educational plan to achieve his "maximum potential").

41. Applicable EAHCA regulations focus significantly on the types of services to be provided pursuant to the Act. See, e.g., 34 C.F.R. $\$ 300.13$ (1984) ("related services" definition); id. at $\$ 300.14$ ("special education" definition); $i d$. at $\S \S 300.305-.307$ (availability of programs and services such as art, music, vocational education, athletics, health services, and physical education). The regulations do not elaborate upon the level and extent of services to be provided, however.

42. See Age v. Bullitt County Pub. Schools, 673 F.2d 141, 144 (6th Cir. 1982); Colin K. v. Schmidt, 536 F. Supp. 1375, 1387 (D.R.I. 1982), affd, 715 F.2d 1 (1st Cir. 1983); Bales v. Clarke, 523 F. Supp. 1366, 1370 (E.D. Va. 1981); Anderson v. Thompson, 495 F. Supp. 1256, 1266 (E.D. Wis. 1980), affd, 658 F.2d 1205 (7th Cir. 1981).

43. See, e.g., Age v. Bullitt County Pub. Schools, 673 F.2d 141, 144 (6th Cir. 1982) (undue interference with development of skills); Colin K. v. Schmidt, 536 F. Supp. 1375, 1387 (D.R.I. 1982) (stagnation or regression), affd, 715 F.2d 1 (1st Cir. 1983); Bales v. Clarke, 523 F. Supp. 1366, 1370 (E.D. Va. 1981) (extraordinary or irretrievable regression); Anderson v. Thompson, 495 F. Supp. 1256, 1266 (E.D. Wis. 1980) (irreparable loss of progress), affd, 658 F.2d 1205 (7th Cir. 1981). 
harmful programming presented such strong proof of a statutory violation that it was unnecessary to consider whether some more stringent standard might otherwise apply. ${ }^{44}$ In other cases, however, it was apparent that the courts regarded the absence of harm, coupled with programming which allowed the child to make some educational gain, as sufficient to satisfy the Act's requirements. ${ }^{45}$ At times, the courts articulated the test in slightly different terms, asking whether the programming had afforded the child an opportunity to make "some progress" toward his educational objectives. ${ }^{46}$ Surprisingly, in view of the apparent laxity of the "some benefit" standard, a significant number of cases determined that the challenged programming failed to comply with the statutory requirement. ${ }^{47}$

In a second class of cases, courts at least gave lipservice to a modified "equivalence of opportunity" standard. ${ }^{48}$ However, no reported decision appears to have attempted to apply such a test in a literal fashion by comparing the objectives of nonhandicapped students against the services provided, and contrasting that shortfall with the corresponding shortfall in opportunity afforded handicapped students in order to determine the relative quality of the respective educational programs. ${ }^{49}$ However, two alternative approaches to determining "equivalence" were used, in each case without explicitly acknowledging the logic underlying the courts' analysis. First, some courts relied upon evidence in the Act's legislative history to conclude that handicapped students should generally be guaranteed an opportunity to gain

44. See, e.g., Colin K. v. Schmidt, 536 F. Supp. 1375, 1387 (D.R.I. 1982), aff d, 715 F.2d 1 (1st Cir. 1983).

45. See, e.g., Age v. Bullitt County Pub. Schools, 673 F.2d 141 (6th Cir. 1982).

46. See, e.g., Norris v. Massachusetts Dep't of Educ., 529 F. Supp. 759, 767 (D. Mass. 1981) (failure to achieve significant growth, lower than expected skill development); Gladys J. v. Pearland Indep. School Dist., 520 F. Supp. 869, 877-78 (S.D. Tex. 1981); Anderson v. Thompson, 495 F. Supp. 1256, 1266 (E.D. Wis. 1980), affd, 658 F.2d 1205 (7th Cir. 1984).

47. Parents succeeded in demanding more extensive programming in several cases. See Colin K. v. Schmidt, 536 F. Supp. 1375 (D.R.I. 1982), affd, 715 F.2d l (1st Cir. 1983); Norris v. Massachusetts Dep't of Educ., 529 F. Supp. 759 (D. Mass. 1981); Gladys J. v. Pearland Indep. School Dist., 520 F. Supp. 869 (S.D. Tex. 1981); Anderson v. Thompson, 495 F. Supp. 1256 (E.D. Wis. 1980), affd, 658 F.2d 1205 (7th Cir. 1981). However, the school systems in large part prevailed in others. See Age v. Bullitt County Pub. Schools, 673 F.2d 141 (6th Cir. 1982); Rettig v. Kent City School Dist., 539 F. Supp. 768 (N.D. Ohio 1981), affd in part, vacated and remanded in part, 720 F.2d 463 (6th Cir. 1983), cert. denied, 104 S. Ct. 2379 (1984); Bales v. Clarke, 523 F. Supp. 1366 (E.D. Va. 1981)

48. See, e.g., Springdale School Dist. v. Grace, 656 F.2d 300, 305 (8th Cir. 1981), vacated, 458 U.S. 1118 (1982), affd on rehearing, 693 F.2d 41, cert. denied, 103 S. Ct. 2086 (1983); Gladys J. v. Pearland Indep. School Dist., 520 F. Supp. 869, 875 (S.D. Tex. 1981); Hines v. Pitt County Bd. of Educ., 497 F. Supp. 403, 406 (E.D.N.C. 1980) (quoting Rowley); Rowley v. Board of Educ., 483 F. Supp. 528, 533-34 (S.D.N.Y.), affd, 632 F.2d 945 (2d Cir. 1980), rev'd, 458 U.S. 176 (1982). This position was also espoused by an influential student law review note which had taken the position that the EAHCA guaranteed handicapped children equal opportunity for individual development that is defined in relationship to the level of opportunity accorded nonhandicapped children in light of services provided to the general student population within a given district. See Note, Enforcing the Right to an "Appropriate" Education: The Education for All Handicapped Children Act of 1975, 92 HARv. L. REv. 1103, $1125-27$ (1979).

49. The district court in Rowley purported to do so, but as explained more fully in section C, instead adopted a more comprehensive equalized opportunity standard. See infra notes 59-62 and accompanying text. 
skills needed to assure self-sufficiency. ${ }^{50}$ At least arguably this approach rests upon the premise that self-sufficiency is the underlying goal of both handicapped and nonhandicapped students; since the system of regular education allows nonhandicapped children to make substantial progress toward that objective, so should the system of special education. Second, at least one court assumed that the opportunities available to handicapped students must be determined by a balancing of their needs against the available resources. ${ }^{51}$ By implication, this balancing process must likewise be used to determine what programming would be provided nonhandicapped students. ${ }^{52}$ The use of an independent balancing calculus for each group might, in at least some circumstances, result in comparable levels of service without the need to engage in literal comparisons between the services afforded handicapped and nonhandicapped students.

Finally, at least one case appears to have adopted an "equalized opportunity standard." ${ }^{3}$ It is to that case-the Rowley case-that we now turn.

III

\section{Level and Extent of Services: Rowley and Beyond}

\section{A. The Rowley Decision}

The facts of the Rowley ${ }^{54}$ case are, by now, well known. ${ }^{55}$ Amy Rowley, an intelligent, highly motivated youngster, suffered, since birth, from a significant hearing impairment. Her parents, also deaf, raised Amy using the "total communication" system of instruction, teaching her to use sign language but also to rely on her limited residual hearing to develop excellent lipreading skills. ${ }^{56}$ When Amy entered first grade in the Hendrick Hudson School Dis-

50. See, e.g., Stacey G. v. Pasadena Indep. School Dist., 547 F. Supp. 61,77 (S.D. Tex. 1982); Rettig v. Kent City School Dist., 539 F. Supp. 768, 777 (N.D. Ohio 1981), affd in part, vacated and remanded in part, 720 F.2d 463 (6th Cir. 1983), cert. denied, 104 S. Ct. 2379 (1984); Gladys J. v. Pearland Indep. School Dist., 520 F. Supp. 869, 875 (S.D. Tex. 1981); Campbell v. Talladega County Bd. of Educ., 518 F. Supp. 47, 54 (N.D. Ala. 1981); Armstrong v. Kline, 476 F. Supp. 583, 604 (E.D. Pa. 1979), remanded sub nom. Battle v. Pennsylvania, 629 F.2d 269 (3d Cir. 1980).

51. See Pinkerton v. Moye, 509 F. Supp. 107, 112 (W.D. Va. 1981).

52. See Bales v. Clarke, 523 F. Supp. 1366, 1371 (E.D. Va. 1981). ("No language in federal law can properly be read as mandating that costs may not be considered in determining what is appropriate for a child-handicapped or nonhandicapped.").

53. Rowley v. Board of Educ., 483 F. Supp. 528, 534 (S.D.N.Y.), affd, 632 F.2d 945 (2d Cir. 1980), rev'd, 458 U.S. 176 (1981) (discussed infra at notes 58-61 and accompanying text). Other courts rejected a similar but more expansive test which would have required school districts to provide handicapped children with an education designed to allow them to achieve their maximum potential. See, e.g., Stacey G. v. Pasadena Indep. School Dist., 547 F. Supp. 61,78 (S.D. Tex 1982).

54. 483 F. Supp. 528 (S.D.N.Y.) affd, 632 F.2d 945 (2d Cir. 1980), rev'd, 458 U.S. 176 (1982).

55. The Supreme Court's decision in Rowley has already, received substantial scholarly attention. See, e.g., Beyer, A Free Appropriate Public Education, 5 W. New ENG. L. Rev. 363 (1983); Zirkel, Building an Appropriate Public Education from Board of Education v. Rowley: Razing the Door and Raising the Floor, 42 MD. L. REv. 466 (1983); Note, Board of Education v. Rowley: The Supreme Court Takes a Conservative Approach to the Education of Handicapped Children, 61 N.C.L. REV. 881 (1983); DuBow, EHLR Analysis: Application of Rowley by Courts and SEAs, 1982-83 EduC. HANdICAPPED L. REP. (CRR) SA-107 (Supp. 93, April 1, 1983); EHLR Analysis: What Rowley Means, 1982-83 EduC. HANdiCAPPED L. REP. (CRR) SA-29 (Supp. 84, Nov. 12, 1982).

56. For a detailed discussion of the total communication method, and other systems of deaf 
trict, in Peekskill, New York, school administrators agreed that she should be placed in a regular classroom and provided with a special hearing aid, a tutor for the deaf who would meet with Amy on a daily basis, and three hours per week of speech therapy. Amy's parents requested that she also be provided a sign language interpreter to accompany her to class, so as to ensure that Amy would continue to rely upon the total communication method. The school district refused to incorporate this additional element into Amy's IEP, citing an earlier determination that a sign language interpreter had been unnecessary to Amy during her participation in the district's kindergarten program, and Amy's good social adjustment and better than average academic performance in the absence of such additional assistance. ${ }^{57}$ The Rowleys unsuccessfully pursued state administrative remedies, and ultimately commenced proceedings in federal district court.

The trial court held in favor of the Rowleys, concluding that the school district's refusal to provide Amy with a sign language interpreter had, indeed, resulted in denial of a "free appropriate public education." 58 The court concluded that the EAHCA's requirement that handicapped children be provided an "appropriate" education meant that Amy should receive something more than an "adequate" education, yet something less than an education which would enable her to achieve her "full potential."59 Instead, the court stated, the Act required that Amy "be given an oportunity to achieve [her] full potential commensurate with the opportunity provided to other children." 60

In the court's view, in order to implement this standard, a reviewing court must necessarily examine three subsidiary questions. First, the potential of the handicapped child in question must be calculated. Second, the child's performance must be assessed and compared to his or her potential. Third, the corresponding "shortfall" between potential and performance of the handicapped child must be compared to that experienced by nonhandicapped children. ${ }^{61}$ In the case at hand, the court reasoned, Amy's potential-measured by her IQ and exceptional level of energy and motivation-was great. The shortfall in educational opportunity she suffered significantly exceeded that of her peers, because she was burdened by a substantial hearing impairment and they were not. ${ }^{62}$ Since provision of a sign language interpreter would eliminate this incremental shortfall in educational opportunity, the school district must supply that service. Thus, although the district purported to apply an "equivalent opportunity" standard, what it adopted instead was an "equalized opportunity" standard-one that required the school district to supply whatever services were needed to minimize the effect of Amy's impairment so

\footnotetext{
education, see Large, Special Problems of the Deaf Under the Education for All Handicapped Children Act of 1975,58 WASH. U.L.Q. 213, 223-40 (1980).

57. 458 U.S. $176,184-85$ (1982).

58. Id. at 176.

59. 483 F. Supp. at 534 .

60. Id.

61. Id.

62. Id. at 535 .
} 
that she might benefit, to the fullest extent possible, from the educational opportunities available to nonhandicapped students.

A divided panel of the Second Circuit affirmed on appeal. ${ }^{63}$ In a per curiam ruling, expressly limiting the holding to the facts at hand without any precedential value, ${ }^{64}$ the appellate majority adopted the district court's reasoning by reference. Judge Mansfield dissented. He urged that an equivalent opportunity standard should be applied in order to ensure that each handicapped child receive an education that would enable him to be as free as reasonably possible from dependence on others. ${ }^{65}$ In his opinion, this standard had been satisfied under the facts at bar.

The United States Supreme Court reversed. ${ }^{66}$ Not surprisingly, however, the Justices were sharply divided, their three opinions reflecting a full range of equality-based approaches to resolving the ambiguity in the EAHCA's free appropriate public education requirement.

Writing for himself and four others, Justice Rehnquist concluded that the laxest of the available standards-the "some benefit" standard-should apply. Resting his analysis upon the statutory text and the legislative history, ${ }^{67}$ he first stated that the EAHCA's requirements could be satisfied "by providing [a handicapped child with] personalized instruction with sufficient support services to permit the child to benefit educationally from that instruction." 68 In discussing the application of that standard, he noted that Congress had intended "that the services provided handicapped children be educationally beneficial, whatever the nature or severity of their handicap," 69 and that "the benefits obtainable by children at one end of the spectrum will differ dramatically from those obtainable by children at the other end, with infinite variations in between."70

Justice Rehnquist was careful to observe that the Court did not attempt "to establish any one test for determining the adequacy of educational benefits conferred upon all children covered by the Act."71 On the facts at hand, however, the majority determined that the test had been satisfied. The Court cited several factors which it believed supported this conclusion: (1) Amy's needs had been specially considered by school administrators; (2) she was receiving special services responsive to her needs; (3) she was enrolled in a regular classroom in which her educational progress was monitored and evaluated as examinations were given, grades awarded, and retention and promotion decisions reached; and (4) she was performing adequately in this

63. 632 F.2d 945 (1980), rev'd, 458 U.S. 176 (1982).

64. Id. at $948 \&$ n. 7 .

65. Id. at 953 .

66. 458 U.S. 176 (1982).

67. See supra notes $25-40$ and accompanying text. The majority also emphasized Congress' desire to ensure that previously unserved children would no longer be excluded from the schools or from specialized educational services. 458 U.S. at 195-97.

68. 458 U.S. at 203.

69. Id. at $202 \mathrm{n} .23$.

70. Id. at 202.

71. Id. 
placement, attaining passing marks and advancing from grade to grade. ${ }^{72}$ While no one of these factors alone would necessarily have been enough to compel the Court's conclusion, ${ }^{73}$ taken together they demonstrated that Amy was receiving an "appropriate" education.

The majority then went on to address a second question, the scope of judicial review, perhaps in order to provide an alternative holding, or perhaps simply to assure that the role of the reviewing court would not, henceforth, be misunderstood. In their view, a two-pronged inquiry is required in actions brought under section 1415(e)(2) of the Act: "First, has the State complied with the procedures set forth in the Act? And second, is the individualized educational program developed through the Act's procedures reasonably calculated to enable the child to receive educational benefits?"74 Since the EAHCA contains detailed procedural requirements designed by Congress to afford important substantive protection, the courts should rigorously enforce such obligations. ${ }^{75}$ On the other hand, according to the majority, reviewing courts must tread more carefully when engaging in direct substantive review. They should accord "due weight" to administrative proceedings, and should refrain from "substitut[ing] their own notions of sound educational policy for those of the school authorities which they review."76

In the majority's view, the Rowley dispute largely focused upon the legitimacy of the school district's decision to adopt a method of instruction other than the total communication method (which would have relied heavily upon the presence of a sign language interpreter). ${ }^{77}$ Since the district court had sought to resolve a difference in opinion concerning the best educational methodology, rather than simply determining whether Amy had received some educational benefit from her program of instruction, it had erred in going beyond the proper scope of judicial review. ${ }^{78}$

Justice Blackmun concurred in the result reached by the majority, but rejected the analytical approach of the Rehnquist opinion in favor of an intermediate "equivalent opportunity" interpretation of the FAPE requirement. In Justice Blackmun's view, the critical issue was whether Amy Rowley's educational program, "viewed as a whole, offered her an opportunity to understand and participate in the classroom that was substantially equal to that given her nonhandicapped classmates."79 In his opinion, the equivalent

72. Id. at $203 \&$ n.25.

73. Id.

74. Id. at 206-07. The Court has recently reiterated its view that the EAHCA both creates "an elaborate procedural mechanism to protect the rights of handicapped children" and "establishes an enforceable substantive right to a free appropriate education," Smith v. Robinson, $104 \mathrm{~S}$. Ct. 3457, 3468-69 (1984), and has stated that a reviewing court must satisfy itself that a child's IEP "conforms with the requirements of $\$ 1401(19)$ [defining such plans]," Irving Indep. School Dist. v. Tatro, 104 S. Ct. 3371,3377 n.6 (1984).

75. 458 U.S. at $205-06$.

76. Id. at 206.

77. Id. at $184-86$.

78. Id. at 207-08 \& n. 29, 209-10.

79. Id. at 211 (emphasis omitted). 
opportunity standard was preferable both to the Rehnquist standard, which focused too narrowly on a handicapped child's achievement of a particular educational outcome (passing from grade to grade), and to the lower court's standard, which focused too narrowly on the presence or absence of a particular service rather than on the handicapped child's overall program. ${ }^{80}$ Since Amy's program, taken as a whole, did offer her an educational opportunity substantially equivalent to that afforded her classmates, it satisfied the requirements of the Act.

Justice White, writing for himself and Justices Brennan and Marshall, dissented, preferring an "equalized opportunity" interpretation of the FAPE obligation. In the view of these three Justices, the Act's guarantee of a free appropriate public education was "intended to eliminate the effects of the handicap, at least to the extent that the child will be given an equal opportunity to learn if that is reasonably possible." 81 Since the aid of a sign language interpreter would effectively equalize Amy's opportunity to learn, one should have been provided. ${ }^{82}$ Moreover, the dissenters concluded, the lower courts had been correct in undertaking a "full and searching" 83 judicial inquiry; Congress's explicit provision for independent judicial review contemplated just that.

\section{B. Critique and Afterword}

The Supreme Court's decision in Rowley may be criticized on at least one score: none of the three competing opinions withstands close analytical scrutiny. Each places a different slant on the ambiguous text and nonspecific legislative history described above. ${ }^{84}$ Yet, because of that ambiguity and lack of specificity, none is able to refute the opposing views in an effective or convincing manner. ${ }^{85}$

Rather than engaging in a protracted discussion of the justifications offered in support of the majority, concurrence, and dissent, it is therefore more profitable to proceed directly to the heart of the matter by assessing the substantive merits of these three views. This section will accordingly examine the implications of the majority's standard to determine whether it assures handicapped children sufficient educational programming to provide them with meaningful educational opportunities. It will then discuss the viability of alternative standards, such as those favored by the concurrence and dissent, in order to ascertain whether a more generous standard was in fact available and might instead have been adopted. It will conclude that, when judged from

\section{Id.}

81. Id. at 215 .

82. Id.

83. Id. at 218 .

84. See supra notes $25-41$ and accompanying text.

85. Both the majority and the dissent relied upon harsh words and competing portions of the legislative history to support their diverse views. Compare 458 U.S. at 190 n. 11 (majority's criticism of dissent) and id. at 191-200 (majority's review of legislative history) with id. at 212 (dissent's criticism of majority) and id. at 213-14, 217-18 (dissent's review of legislative history). 
this perspective, the majority's standard represents a sound and perhaps inevitable interpretation of the Act's FAPE requirement.

1. Assurance of meaningful educational opportunity. Whether meaningful educational opportunity will be afforded handicapped students as a result of the Rowley decision will depend upon the interplay of the two critical issues discussed in that decision-first, the substantive standard governing programming decisions, and second, the scope of judicial review.

A threshold question is whether Rowley's "some benefit" standard requires a single-pronged or double-pronged substantive inquiry. It might be contended that Rowley merely contemplates that each handicapped child receive some net educational benefit, without attempting to measure that benefit against the child's individual goals and objectives. ${ }^{86}$ A much stronger case can be made for a two-pronged approach, however, since the EAHCA specifically provides that each child's educational program is to be designed with his individual needs in mind. ${ }^{87}$ If the sufficiency of the programming to be provided is not similarly assessed with the child's unique abilities, needs, and objectives in mind, that requirement would be largely nugatory. The Rowley decision itself specifically recognized that the "some benefit" standard could only be applied after careful consideration of each individual child's abilities, needs, and objectives. ${ }^{88}$ Accordingly, a two-pronged analysis of the substantive sufficiency of educational programming should be employed: This analysis requires both careful examination of the child's abilities, needs, and objectives, and an assessment of whether he is receiving some educational benefit as measured against those objectives.

The first prong of this test-examination of the child's abilities, needs, and objectives-is particularly critical. In the absence of careful and accurate judgments on these issues, the second-stage inquiry into benefit derived will be based upon an incorrect benchmark, virtually assuring that the child will not receive an "appropriate" education. Thus, if a child's goals and objectives are set at a very modest level as a result of an incorrect diagnosis of mental retardation or an erroneous assessment of the extent to which his mental capacity is impaired, an inquiry into his attainment of the established goals would fail to ensure that he has, in fact, received educational programming which "meets his unique needs." 89 Following Rowley, it is therefore quite likely that more attention will be focused upon the nature of individual

86. The Rowley majority at times uses broad language which could provide support for such a view. See, e.g., 458 U.S. at 195 ("the Act imposes no clear obligation upon recipient States beyond the requirement that handicapped children receive some form of specialized education"); id. at 196 (Congress sought to ensure that handicapped children were "served" and " "served' referred to children who were receiving some form of specialized educational services").

87. See 20 U.S.C. $\$ 1401(16)$ quoted in text accompanying note 32 supra.

88. See 458 U.S. at 202,203 n.25 (observing that the Court did not intend to hold that "every child who is advancing from grade to grade in a regular public school system is automatically receiving a 'free appropriate public education,'" but that Amy Rowley had received such an education in view of her actual progress, the services she had received, and the "professional consideration" she had been afforded).

89. See, e.g., Campbell v. Talladega County Bd. of Educ., 518 F. Supp. 47, 55 (N.D. Ala. 1981) 
handicapped children's disabilities. The precise nature of such children's educational needs-including needs for emotional as well as intellectual development-is also likely to become an even more prominent factor in educational programming decisions. ${ }^{90}$ Finally, an increased number of challenges may well be directed to the adequacy of the objectives and goals stated in the child's IEP,91 for unless those objectives are detailed and comprehensive in character, review of the sufficiency of educational benefits received must, at best, be cursory.

Under this first prong of the substantive inquiry into the adequacy of educational programming, judicial review may be limited when the school and the parents agree on a particular child's abilities, needs, and objectives. ${ }^{92}$ In the event of disagreement, however, that review should be more probing. Such review necessitates careful review of professional diagnoses of the child's handicapping condition and evaluations of the impairment to his learning abilities that exists as a result. These issues are, by and large, factual in character. ${ }^{93}$ In discussing the standard of review for such factual issues, some lower courts have tended to limit the Supreme Court's caution in Rowley, regarding factual review of school districts' judgments, to disagreements about educational methodology. ${ }^{94}$ Courts have also concluded that "due weight" is afforded determinations by state and local hearing officers on other, nonmethodological issues so long as evidence adduced and findings reached in administrative proceedings are not wholly ignored by the trial court. ${ }^{95}$ The trial court thus retains the ultimate responsibility of making factual findings on such issues as the handicapped child's abilities, needs, and

(FAPE not provided where program for severely mentally retarded boy did not take into account his individual needs and abilities.).

90. See, e.g., Crawford v. Pittman, 708 F.2d 1028, 1033-35 (5th Cir. 1983) (must assess needs); Lee v. Thompson, 1982-83 Educ. Handicapped L. ReP. (CRR) 554:429 (D. Hawaii 1983) (must consider nature and severity of handicap and areas of learning crucial to attaining self-sufficiency); In re J.B., 1982-83 Educ. Handicapped L. ReP. (CRR) 504:319 (Vt. SEA 1983) (must first consider child's needs to determine whether vocational educational programming is appropriate); see also infra part IV for discussion of scope of educational needs for purposes of the EAHCA.

91. See, e.g., Case No. SE-99-80, 1982-83 Educ. Handicapped L. Rep. 504:267 (Ill. SEA 1983) (dispute regarding suitability of academic versus vocational objectives); In re Hershey Pub. School Dist. No. 37, 1982-83 Educ. Handicapped L. ReP. (CRR) 504:225 (Neb. SEA 1982) (same).

92. This was apparently the case in Rowley. See 483 F. Supp. 528, 529 (S.D.N.Y.), affd, 632 F.2d 945 (2d Cir. 1980), rev'd, 458 U.S. 176 (1981).

93. See, e.g., Colin K. v. Schmidt, 715 F.2d 1, 6 (1st Cir. 1983); Case No. SE-99-80, 1982-83 Educ. Handicapped L. ReP. (CRR) 504:267 (Ill. SEA 1983).

94. See, e.g., Roncker v. Walter, 700 F.2d 1058, 1062 (6th Cir. 1983), cert. denied, 104 S. Ct. 196 (1983).

95. See, e.g., Abrahamson v. Hershman, 701 F.2d 223, 230 (1st Cir. 1983). But see Roncker v. Walker, 700 F.2d at 1062 (trial court failed to accord due weight when reversing decision of local and state hearing officers that proposed programming was inappropriate). Roncker may suggest that a differential standard of review is being applied depending on whether state and local hearing officers uphold or reject a local school district's decision. A federal court may fear that a hearing officer's decision in favor of a local school district may reflect favoritism toward the district's point of view, and may, therefore, step in to protect the interest of the handicapped children whom the EAHCA is designed to protect. Such a court may be inclined to give greater deference to determinations by hearing officers which necessarily reflect an independent judgment which differs from that of the school district, triggering no similar fear of favoritism. 
objectives. ${ }^{96}$ In reaching such decisions, trial courts and hearing officers are nevertheless likely to treat professional judgments as particularly persuasive, especially where such judgments are those of teachers or other personnel who have worked with the handicapped child over an extended period. ${ }^{97}$ They may also give serious consideration to the insights of parents, who in many cases have considerable knowledge of their child's abilities and needs, regardless of their backgrounds in educational methodology. ${ }^{98}$

Assessment of the benefit afforded by the educational programming in question, under the second prong of the substantive standard, is likewise of great importance. The Supreme Court's decision in Rowley has shaped this inquiry in two key respects. First, while the benefit afforded must ultimately be evaluated in light of an individual child's narrow educational objectives, benefit itself is not a narrow concept. Instead, it includes the net advantages gained, not simply from one facet, but from the whole of the child's educational environment-the educational methods used, the personnel employed, the intensity of services afforded. Accordingly, following Rowley, attention has turned to the general benefit derived from the total mix of services offered a handicapped child-his overall educational opportunity-rather than the adequacy or inadequacy of a single aspect of his educational program. ${ }^{99}$ Second, the Court clearly stated that the benefit afforded need not be sufficient to allow the child in question to actually attain his full educational potential. ${ }^{100}$ The Court indicated that the sufficiency of the child's educational programming is to be judged by his performance in making incremental progress toward his individual educational goals. It thus established an objective threshold standard of sufficiency that appears to guarantee each handicapped child at least minimal eductional opportunity.

96. Abrahamson v. Hershman, 701 F.2d at 230; School Comm. v. Massachusetts Dep't of Educ. (Burlington), 736 F.2d 773, 790 (1st Cir. 1984), cert. granted, 53 U.S.L.W. 3414 (Dec. 4, 1984). A more limited federal interest thus exists to justify intervention by the federal courts under these circumstances. School Comm. v Massachusetts Dep't of Educ. (Burlington), 736 F.2d 773,792 (1st Cir. 1984) (adopting "a symmetrical" approach envisioning greater judicial deference to decision of state hearing officers determining that IEP did not comply with requirements of state law), cert. granted, 53 U.S.L.W. 3414 (Dec. 4, 1984).

97. See, e.g., In re West Brookfield Pub. Schools, 1982-83 Educ. Handicapped L. ReP. (CRR) 504:166 (Mass. SEA 1982) (home teacher); In re Brockton Pub. Schools, 1982-83 Educ. HandCAPPED L. REP. (CRR) 504:128 (Mass. SEA 1982) (primary teacher, therapists, evaluators); In re Dixie School Dist. and Marin County Special Educ. Consortium, 1982-83 Educ. HandiCAPPEd L. REP. (CRR) 504:274 (Cal. SEA 1983) (current teachers and interpreter).

98. See Davis v. District of Columbia Bd. of Educ., 522 F. Supp. 1102,1109 (D.D.C. 1981) (parents' views are to be thoroughly considered; may be biased or highly probative); In re Madison Metropolitan School Dist., 1981-82 Educ. Handicapped L. ReP. (CRR) 503:125 (Wis. SEA 1981) (parents' wishes are to be considered, but do not control). But see Johnston v. Ann Arbor Pub. Schools, 569 F. Supp. 1502, 1509 (E.D. Mich. 1983) (refusing to substitute mother's judgment for judgment of professionals).

99. See, e.g., Rettig v. Kent City School Dist., 720 F.2d 463, 466 (6th Cir. 1983) (mix of services adequate without provision of summer classes and occupational therapy), cert. denied, $104 \mathrm{~S} . \mathrm{Ct} .2379$ (1984). Cothern v. Mallory, 565 F. Supp. 701, 707-08 (W.D. Mo. 1983) (considering teacher training, integration with nonhandicapped children, and other factors).

100. See 458 U.S. at 192 (quoting Senate report which expressly recognized that "in many instances the process of providing special education and related services to handicapped children is not guaranteed to produce any particular outcome”). 
Whether even this minimal opportunity will in fact be afforded depends, however, upon the judicial review applied to this second, assessment-of-benefit facet of the test for substantive sufficiency of educational programming. Most of Rowley's strong cautionary language regarding the scope of judicial review seemed to be addressed to this prong of the analysis, since there was little question regarding Amy's abilities, needs, or objectives. Not surprisingly, several competing interpretations of the Court's statements regarding the scope of judicial review are possible. One view is based on the Court's repeated references to the broad authority of state and local school officials over questions of educational policy. Under this view, since all programming determinations involve decisions abcut educational methodology to some degree, school officials, not the courts, should be allowed to determine what constitutes adequate educational benefits, either during the local IEP development or the state administrative review process. For example, the courts would largely defer to school officials' determination of whether a seriously learning disabled child, who also suffered from associated emotional problems, would derive "some" educational "benefit" from instruction in a self-contained classroom with a 10 to 1 pupil-teacher ratio, or whether a more individualized, highly structured, and closely supervised program would instead be required. ${ }^{101}$

Alternatively, the Court's remarks could be seen to limit the scope of judicial review only in relatively few cases, where parents disagree with school officials regarding which of several professionally acceptable techniques or modes of instruction should be employed. ${ }^{102}$ Under this view, trial courts would remain relatively free to reach independent, de novo judgments regarding the sufficiency of educational programming in other respects.

The appropriate scope of judicial review under the second prong of Rowley's substantive standard probably lies somewhere between these two extremes. The Court's rather indiscriminate references to educational method and policy probably were not limited to theories of instruction. ${ }^{103}$ At the same time, the Court did not suggest that school officials' judgments on these questions should go altogether unchecked. Instead, the Court specifically directed that reviewing courts were to determine whether the mix of methods, personnel, and other facets of a child's educational program carried

101. This view was rejected in Colin K. v. Schmidt, 715 F.2d 1, 6 (1st Cir. 1983). However, other courts have adopted such a view on comparable facts. See Johnston v. Ann Arbor Pub. Schools, 569 F. Supp. at 1507-09 (court hesitated to substitute its judgment for that of school official in case involving 11-year-old girl with cerebral palsy who requested placement in specialized school for physically impaired after experiencing significant learning difficulties in local placement); see also Rettig v. Kent City School Dist., 720 F.2d 463, 466 (6th Cir. 1983) (stating that programming decisions are within state's discretion, but holding, in the alternative, that requested services were unnecessary), cert. denied, 104 S. Ct. 2379 (1984).

102. See Roncker v. Walter, 700 F.2d 1058, 1062 (6th Cir. 1983) (distinguishing decisions regarding methodology from those regarding mainstreaming), cert. denied, $104 \mathrm{~S}$. Ct. 196 (1983).

103. The Court undertook an extended discussion of the scope of review, warning reviewing courts against using a free hand to impose substantive standards of review which are not derived from the Act itself and emphasizing that Congress had intended the Act's procedural requirements to assure compliance with its substantive requirements. 458 U.S. at 206. 
him across the statutory threshold, immunizing him from harm, and assuring him of some incremental progress toward his objectives. ${ }^{104}$ Because these latter questions are questions of fact, ${ }^{105}$ they may be addressed by the courts without fear of violating state and local prerogatives to determine the means used to reach a statutorily mandated end.

Again under this factual review, the courts will undoubtedly accord considerable weight to the professional judgments of school personnel. ${ }^{106}$ At the same time, the child's track record is likely to be more compelling evidence than educators' projections. ${ }^{107}$ In doubtful cases, a court may order especially close monitoring of a child's progress to assure that his educational program will be modified if the minimum opportunity is not provided. ${ }^{108}$ In other cases, especially where the child is so seriously impaired that a marginally effective educational program creates substantial risks (risk of harm through regression, or the risk of inability to make even some progress toward identified educational objectives), the court may well find that the program is inadequate. ${ }^{109}$ In such instances, it is likely that the court or other reviewing body will order some specific remedy-a change in instructional personnel, a change in the type or level of sevices provided, or some other program modification-rather than leaving completely to school officials the decision regarding the proper scope of the child's program. ${ }^{110}$

Thus, the decision in Rowley appears to guarantee that, under the EAHCA, handicapped children will receive at least a minimally adequate education, one that is designed to meet their individual abilities, needs, and objectives and that will assist them in achieving at least some progress toward their goals. Although the authority of reviewing courts has been limited in at least some respects, they may be expected to continue to play a key role in ensuring that this threshold statutory standard is met. The standard adopted by the Rowley majority is, on its face, a sound one. This judgment is further confirmed by a comparative analysis of the more generous alternative standards proposed by the Rowley concurrence and dissent.

2. Availability of Alternative Standards. Examination of possible alternative standards suggests that the Supreme Court in Rowley bowed to the inevitable

104. Id. at $203 \mathrm{n} .25$ (determining that Amy Rowley received appropriate education in view of professional consideration received, special services provided, and academic progress achieved).

105. See Abrahamson v. Hershman, 701 F.2d 223, 230 (1st Cir. 1983); Doe v. Anrig, 692 F.2d 800, 806 \& n. 12 (1st Cir. 1982), on remand, 561 F. Supp. 121 (D. Mass. 1983), affd, 728 F.2d 30 (1st Cir. 1984).

106. See, e.g., Lang v. Braintree School Comm., 545 F. Supp. 1221, 1225-26 (D. Mass. 1982).

107. See Doe v. Anrig, 692 F.2d at 807-08.

108. See In re Burton School Dist., 1982-83 Educ. HandiCapped L. Rep. (CRR) 504:133 (Cal. SEA 1982); see also Laura M. v. Special School Dist. \#1, 1980-81 Educ. HANDiCAPPED L. ReP. (CRR) 552:152 (D. Minn. 1980).

109. See, e.g., In re Burton School Dist., 1982-83 Educ. Handicapped L. ReP. (CRR) 504:133 (Cal. SEA 1982); In re Putnam City School Dist., 1982-83 Educ. HANDICAPPEd L. ReP. (CRR) 504:207 (Okla. SEA 1982).

110. See, e.g., Abrahamson v. Hershman, 701 F.2d 223 (1st Cir. 1983) (custodial services for severely retarded child); In re Scottsbluff Pub. School, 1982-83 Educ. HandiCapPed L. REP. (CRR) 504:238 (Neb. SEA 1982) (preschool service for profoundly deaf child). 
in adopting a "some benefit" standard for determining the sufficiency of educational programming under the EAHCA. The Court selected the only one of the three possible standards which avoided problems of justiciability that have long influenced the development of equal educational opportunity jurisprudence. Academic and judicial discussion of justiciability during the last twenty years has focused on two principal concerns. First, federal courts have hesitated to assume the task of allocating public resources in an equitable fashion to assure equality of opportunity. ${ }^{111}$ The courts have long understood that the process of resource allocation is, by its nature, largely a political one. Except where a disadvantaged group is denied all opportunity (a strong indication that the political process has gone awry and that judicial intervention is warranted), or inhumane conditions exist, ${ }^{112}$ the courts have generally concluded that resolution of political disputes should be left to the legislative arena. ${ }^{113}$ This general hesitancy to assume responsibilities for resource allocation has applied equally in the educational context.114

Second, the courts have recognized that, even apart from resource allocation problems, it is particularly difficult to develop judicially manageable standards for determining whether educational opportunities have been allocated in an "equal" fashion.115 Many scholars agree that "educational opportunity" does not refer to educational "output," that is, an individual's achievement of noneducational goals by using the intellectual and practical skills he acquired through education, as well as his own talent, energy, and other available resources. ${ }^{116}$ Assuming that educational opportunity is defined in terms of "input," rather than "output," a question arises as to the precise "input" to be measured, for example, monetary contributions versus other more intangible resources. ${ }^{117}$ In addition, scholars differ on the proper measurement of the sufficiency of that "input" to meet affected children's needs. ${ }^{18}$ Courts have hesitated to undertake a comparison of the opportunities afforded on a school district by school district basis. ${ }^{119}$ Comparison on a child-by-child basis could only prove significantly more cumbersome.

The "some benefit" standard surmounts both these justiciability concerns. First, it allows the courts to confine their involvement in resource allocation decisions within traditionally acceptable bounds. Rather than having to balance myriad competing claims to limited available resources, courts only must

111. See, e.g., Dandridge v. Williams, 397 U.S. 471 (1970).

112. See, e.g., Wyatt v. Stickney, 344 F. Supp. 373, (M.D. Ala. 1972) (inhumane conditions in institution for mentally retarded), aff $d$ in part, remanded in part, sub nom. Wyatt v. Aderholt, 503 F.2d 1305 (5th Cir. 1974); Gates v. Collier, 349 F. Supp. 881 (N.D. Miss. 1972) (inhumane prison conditions), affd, 501 F.2d 1291 (5th Cir. 1974).

113. Dandridge v. Williams, 397 U.S. 471 (1970).

114. See, e.g., San Antonio Indep. School Dist. v. Rodriguez, 411 U.S. 1, 35 (1973).

115. See id. at 42; Battle v. Pennsylvania, 629 F.2d 269, 277 (3d Cir. 1980), cert. denied, 452 U.S. 968 (1981); McInnis v. Shapiro, 293 F. Supp. 327, 335-36 (N.D. Ill. 1968) (three judge panel), affd sub nom. McInnis v. Ogilvie, 394 U.S. 322 (1969).

116. See, e.g., Haggerty \& Sacks, supra note 8, at 972-73; Schoettle, supra note 3, at 1373.

117. Schoettle, supra note 3, at 1369-70.

118. Id. at 1371-72.

119. See San Antonio Indep. School Dist. v. Rodriguez, 411 U.S. 1 (1973). 
assure that no individual is denied resources needed to allow him to receive effective, personalized instruction, and thus at least minimal access to an important, publicly funded opportunity. The "some benefit" standard thus allows the courts to adopt the least intrusive possible posture in dealing with resource allocation questions. They can require schools, without exception, to provide all students with a minimum level of opportunity, while leaving to school officials the task of allocating available resources that exceed this amount as they see fit. ${ }^{120}$

Second, the "some benefit" standard provides judicially manageable criteria for determining whether equal educational opportunity has been afforded. On the one hand, it assumes that opportunity comprises the sum total of all facets of a handicapped child's educational environment, thereby shielding a reviewing court from demands that it evaluate the adequacy of independent components of that environment-for example, teaching skill, or method and intensity of instruction-which are peculiarly insusceptible to judicial review. On the other hand, it requires the reviewing court to assess the adequacy of the child's educational program in practical and measureable terms, by focusing on the individual handicapped child alone, without the need for assessing and comparing the opportunity afforded any other children enrolled in the public school system. As in Rowley, a court need only inquire whether the child's needs and objectives have been properly determined (e.g., was the extent of Amy's hearing impairment accurately diagnosed and her instructional objectives reasonably defined to include at least normal academic progress for a child of her age?), and whether the child can reasonably be expected to make some discernible progress toward those objectives (Can Amy continue to achieve at or above normal grade level?).

Neither of the competing alternative standards could similarly surmount these two longstanding justiciability concerns. Each of the possible formulations of the "equivalent opportunity" test runs afoul of one or another justiciability problem. Under the more viable of the two pre-Rowley "equivalent opportunity" approaches, for example, a reviewing court would be required to balance the opportunity afforded the handicapped child against the resources available. Therefore, a court would be required to engage directly in the allocation of public resources, without the assistance of any judicially manageable guidelines. ${ }^{121}$ Under Justice Blackmun's approach in Rowley, direct comparison of opportunities afforded handicapped and nonhandicapped children would be required, again with no hint of how the possibly very different components of these educational programs would be assessed, averaged, and translated into units appropriate for comparison.

Similarly, the "equalized opportunity" standard is seriously flawed. In theory, this standard would not require direct consideration of allocation issues. Instead, school districts would have to afford those services needed to

120. See Bartlett, The Role of Cost in Educational Decisionmaking for the Handicapped Child, LAw \& Contemp. Probs., Spring 1985, at 7.

121. See supra note 51 and accompanying text. 
minimize the effects of a child's handicapping condition, regardless of cost, unless they could offer a statutory cost defense. ${ }^{122}$ In practice, however, there would undoubtedly be insufficient resources to provide the optimal services necessary to overcome the effects of a child's handicap to the maximum extent possible. The courts would thus be inexorably drawn into allocating the resulting shortfall in overall resources between handicapped and nonhandicapped students. Since no judicially manageable standards for that process of allocation are provided, this option is an unpalatable one.

Even if the sufficiency of public resources posed no problem, an additional difficulty would remain. Under the equalized opportunity test, the court would be expected to determine whether the educational services provided were those which most nearly minimized the effects of a particular child's handicap, thereby allowing him to benefit as fully as possible from the opportunities afforded nonhandicapped students. This task is a troublesome one. As was the case in Rowley, the standard would draw the courts into deciding, on a recurring basis, which of several possible techniques should be used to minimize the effects of a child's handicap as fully as possible. Since there is often considerable professional disagreement concerning which is the "best" instructional technique currently available, use of the "equalized opportunity" standard would force the courts to resolve issues that are peculiarly beyond the judicial province. Thus, for this reason as well, the "equalized opportunity" standard presents serious justiciability problems.

Recent developments under state special education statutes confirm these observations. Following the Supreme Court's decision in Rowley, it was predicted that state courts might choose to impose a more stringent standard under state law than that adopted by the Court for purposes of the EAHCA. ${ }^{123}$ Although litigants have attempted to invoke a more stringent state standard in a number of administrative appeals and cases, the approach has generally been unsuccessful. ${ }^{124}$ In several instances, it has been determined that state law requires the adoption of educational objectives that reflect a handicapped child's maximum potential. ${ }^{125}$ However, no more than measurable progress toward those objectives has generally been required,

122. See Bartlett, supra note 120 , at 38 .

123. See Zirkel, supra note 55, at 487-91.

124. See, e.g., Max M. v. Thompson, 566 F. Supp. 1330 (N.D. Ill. 1983) (interpreting Illinois law); Cothern v. Mallory, 565 F. Supp. 701 (W.D. Mo. 1983) (interpreting Missouri law); Harrell v. Wilson County Schools, 58 N.C. App. 260, 293 S.E.2d 687 (1982), appeal dismissed, 306 N.C. 740, 295 S.E.2d 759, cert. denied, 460 U.S. 1012 (1983); In re Traverse Bay Area Intermediate School Dist., 1982-83 Educ. Handicapped L. Rep. (CRR) 504:140 (Mich. SEA 1982); $c f$. Buchholtz v. Iowa Dep't of Pub. Instruction, 315 N.W.2d 789, 793 (Iowa 1982) (pre-Rowley decision).

125. See Cothern v. Mallory, 565 F. Supp. 701 (W.D. Mo. 1983) (Missouri statute requires schools to meet the needs and maximize the capabilities of handicapped children); Harrell v. Wilson County Schools, 58 N.C. App. 260, 265, 293 S.E.2d 687, 690 (1982) (interpreting North Carolina State statute guaranteeing an "appropriate" education in light of legislative purpose to ensure every child an opportunity to achieve his full potential and concluding that statute embodied standard proposed by Rowley dissenters); In re Traverse Bay Area Intermediate School Dist., 1982-83 Educ. HANDICAPPED L. REP. (CRR) 504:140 (Mich. SEA 1982) (interpreting Michigan state statute as requiring provision of education designed to achieve child's maximum potential); Buchholtz v. Iowa Dep't of Pub. Instruction, 315 N.W.2d 789, 793 (Iowa 1982) (interpreting Iowa statute to require 
consistent with the federal "some benefit" test. 126

In sum, the Supreme Court in Rowley very likely had little choice but to adopt a "some benefit" standard for determining the sufficiency of educational programming under the EAHCA. While that standard does not afford the degree of protection that some advocates would prefer, it continues to afford courts adequate leeway to ensure that some meaningful educational opportunity is afforded each handicapped child.

\section{IV}

\section{Scope of Educational NeEds}

As has just been described, a handicapped child's abilities and attendant needs, goals and objectives, play a critical role in determining the level and extent of services provided pursuant to the EAHCA. A second, related question accordingly comes readily to mind: What range of needs must school districts address in developing a child's educational program?

Careful analysis of this question is required, for the stakes are high. If the range of needs to be addressed under the EAHCA ("educational needs") is a narrow one, and schools are relieved of any obligation to provide services which respond to noneducational needs, the extent of services available under the Act may be significantly curtailed. If, on the other hand, educational needs are defined as very broad in scope, school districts may regularly face demands for a wide array of very expensive noninstructional services. Not surprisingly, for example, the scope of educational needs to be addressed under the Act has become a recurrent question in cases in which parents have requested placement of severely impaired children in intensive, comprehensive residential programs. School districts have agreed, in many instances, to cover costs of instructional services attendant to such placements. However, they have declined to pay for expensive ${ }^{127}$ counseling, custodial and medical services which often form an integral part of such residential programs, arguing that such noninstructional services address noneducational needs

provision of a level of education commensurate with the level provided each child who does not receive special education).

126. See Cothern v. Mallory, 565 F. Supp. 701 (W.D. Mo. 1983) (programming provided child with Down's syndrome sufficient under both state and federal standards despite parents requests for additional services and more fully trained personnel); Harrell v. Wilson County Schools, 58 N.C. App. 260, 293 S.E.2d 687 (1982) (hearing impaired child received sufficient education under both federal and state standards where she was placed in mainstream setting with unspecified amount of assistance from resource personnel and was "progressing with her studies"); In re Traverse Bay Area Intermediate School Dist. 1982-83 EDUC. HANDICAPPED L. REP. (CRR) 504:140 (Mich. SEA 1982) (profoundly hearing impaired child need not be provided cued speech interpreter while enrolled in mainstream classes for substantial part of day, notwithstanding state statute incorporating maximum potential standards); Buchholtz v. Iowa Dep't of Pub. Instruction, 315 N.W.2d 789 (Iowa 1982) (child with learning disability not guaranteed "best" education available in neighboring school district under Iowa "commensurate education" standard). But see David D. v. Dartmouth School Comm., 1984-85 Educ. Handicapped L. ReP. (CRR) 556:215 (D. Mass. 1984) (awarding relief based on more protective Massachusetts state law); Geis v. Board of Educ., 1984-85 Educ. HandicapPEd L. REP. (CRR) 556:208 (D.N.J. 1984) (awarding relief based on more protective New Jersey state law).

127. See Stanger v. Ambach, 501 F. Supp. 1237, $1241-42$ (S.D.N.Y. 1980) (discussing residential placement that would cost $\$ 53,832$ for the $1980-81$ year); Stark, supra note 11 . 
outside the realm of their statutory obligations. ${ }^{128}$ Parents, on the other hand, have urged that the full range of instructional and noninstructional services are needed to allow their child to make even minimal educational progress, and that such programming should accordingly be deemed to address educational needs.

Debate over the scope of educational needs may be motivated by practical concerns to avoid substantial drains on limited school budgets and to protect the welfare of severely impaired children, but it is often waged in more theoretical terms which once again can fruitfully be examined by reference to the concept of equal educational opportunity. The position of many school districts that the scope of educational needs under the Act should be narrowly defined rests on the unstated premises that the EAHCA is designed to assure equal educational opportunity, and that such opportunity can best be defined by reference to the traditional school system. In that context, educational needs are commonly understood to be synonymous with needs uniquely and historically addressed by educational institutions, through provision of instructional services by trained personnel. Noneducational needs are those historically addressed by other institutions, through the provision of other types of services by personnel with different sorts of training. Under this approach, a dichotomy is assumed to exist between mutually exclusive classes of educational and noneducational needs. If this exclusionary approach were incorporated as an aid in determining the scope of needs to be addressed under the EAHCA, it would therefore follow that programming which meets noneducational needs falls outside the range of schools' statutory obligations.

A different view of equal educational opportunity has underlain arguments of parents and advocates in support of a broader interpretation of the scope of educational needs under the EAHCA. They have claimed that the Act contemplates a more substantial modification of the traditional approach to defining schools' responsibilities to address children's educational needs, and have urged that the traditional dichotomy between educational and noneducational needs be recast or replaced by an inclusionary approach to the definition of educational needs. Under this view, the assumption that educational and noneducational needs are mutually exclusive would be rejected, and programming required to address a child's educational needs would be provided, even though it simultaneously responds to noneducational needs.

Section A explores the guidance provided by the text of the Act and agency regulations regarding which of these alternative interpretations should be employed. Section B demonstrates that the weight of case law has correctly adopted a broad inclusionary approach to delineating those needs that are to be regarded as educational in character, for purposes of the EAHCA.

128. School districts have also urged that placement in residential programs would violate the statutory requirement that handicapped children be educated in the least restrictive environment. 


\section{A. Statutory and Regulatory Text}

While neither statutory text nor pertinent regulatory provisions are free of ambiguity, both suggest that a broad inclusionary interpretation of educational needs is preferable. Educational need, for purposes of the EAHCA, cannot be understood by referring to a single section of the statute. Instead, one must discern the significance of several interlocking provisions. The definitions of "special education" and "related services" provide a critical starting point. The special education component of a child's free appropriate public education is to include "instruction . . . to meet [his] unique needs." 129 This unqualified reference to the child's needs suggests that the instruction in question may have to address the full spectrum of needs experienced by the child. In addition, the related services to be provided are defined in broad terms. For example, "supportive" and "psychological services" may be required, services which necessarily both foster a child's academic performance and respond to his emotional needs. ${ }^{130}$

A limit upon school systems' obligations to meet handicapped children's needs appears elsewhere in the Act, however. Special education and related services must be supplied only as required to ensure that a child receive a free appropriate public education. ${ }^{131}$ EAHCA defines that education, in turn, as the composite of services identified through the IEP development process. 132 The IEP is to include a "statement of present levels of educational performance," a statement of "annual goals, including short-term instructional objectives," and criteria for determining whether these objectives are being achieved. ${ }^{133}$

This language could be interpreted narrowly as focusing upon the process of instruction, confirming some schools' exclusionary view that emotional and custodial needs remain beyond the scope of their responsibilities. However, a broader interpretation seems more supportable. The educational performance and instructional goals in question are those of the full range of handicapped children identified elsewhere in the Act. ${ }^{134}$ Thus, because of their seriously impaired abilities, some children require instruction in coping and self-care skills in addition to, or instead of, traditional academic instruction. Congress was fully advised of this fact during extensive hearings which preceded the EAHCA's enactment. ${ }^{135}$ Moreover, Congress was also aware that it might be impossible to provide instruction that allows such children to make even limited progress toward the attainment of these skills except through

129. 20 U.S.C. $\S 1401(16)(1982)$.

130. See infra text accompanying note 175 for quotation of this portion of the "related services" definition.

131. 20 U.S.C. $\$ 1401(18)$ (1982) (a definition of "free appropriate public education" is quoted supra at note 27 ).

132. Id.

133. 20 U.S.C. $\$ 1401(19)$ (1982).

134. See supra note 25 for the definition of "handicapped children" which includes mentally retarded and seriously emotionally disturbed children.

135. See 1973 Senate Hearings, supra note 6, at 99, 391-92, 798, 808. 
means that simultaneously address their emotional and custodial care needs. ${ }^{136}$ The better reading of these provisions is, therefore, that they justify a broad inclusionary interpretation.

Agency regulations, while also ambiguous, appear likewise to support this broad view. EAHCA regulations regarding the availability of residential programming state: "If placement in a public or private residential program is necessary to provide special education and related services to a handicapped child, the program, including nonmedical care and room and board, must be at no cost to the parents of the child." 137 A cryptic comment accompanying the rule has proved more important than the statutory text: "This requirement applies to placements which are made by public agencies for educational purposes . . . ."138 This regulation, and the accompanying comment, clearly indicate that schools may have to address custodial care needs. Moreover, the regulators' reference to "educational purposes," rather than "educational needs," may suggest a desire to abandon the traditional dichotomy between educational and noneducational needs. The word "purposes" can reasonably be seen to embrace a wider range of needs, in effect redefining the notion of educational needs in a more comprehensive fashion such as that required by the inclusionary interpretation under consideration here. The regulation is not, however, altogether free from ambiguity in this regard. One construction of the reference to "educational purposes" is that it is an express recognition that some residential placements may be made because of children's emotional needs, and that those placements need not be funded publicly. The regulation, though, makes no reference to schools' responsibilities to address custodial care needs which exist in nonresidential settings and which may likewise give rise to educational needs or affect schools' abilities to address instructional needs in an effective fashion. Although the statutory and regulatory text provides some guidance concerning the definition of educational needs to be adopted for purposes of the EAHCA, it is not surprising that the issue has continued to spur debate and has accordingly required resolution by administrative hearing officers and by the courts.

\section{B. Judicial and Quasi-Judicial Interpretations}

As suggested above, there is a pronounced split in quasi-judicial and judicial interpretations of the scope of educational needs which must be addressed under the EAHCA. The following discussion examines and evaluates a typical administrative hearing officer decision adopting a narrow exclusionary approach, and then traces the courts' development of a better reasoned inclusionary interpretation.

136. Id.

137. 34 C.F.R. $\$ 300.302$ (1984).

138. Id. 
1. Exclusionary Approach. In re M.J.S. is a recent New Jersey hearing officer decision which exemplifies the exclusionary approach. ${ }^{139}$ In that case, the father of a 17-year-old emotionally disturbed girl requested that she be provided with residential programming. The girl had become a routine truant and an alcohol and drug abuser following her parents' divorce. She was placed by her parents in a residential program, where she performed above average academically until removed for treatment and evaluation in a specialized hospital facility. The hospital staff recommended that upon release she be placed again in a residential setting in order to receive both an appropriate academic program and training in behavior modification accompanied by therapy, the latter designed to deal with her emotional needs. After an unsuccessful attempt to place the girl in local programming, including some mainstream classes, the school system agreed that her educational program should be revised. While expressing a willingness to fund the educational component of the proposed residential program, the school refused to cover other expenses such as those associated with room and board. The board supported this position by contending that it could provide an adequate local private day program for the girl in order to meet her educational needs. It further contended that residential programming was being requested for noneducational purposes-specifically to meet her emotional needs and to relieve her father of undesired supervisory responsibilities which interfered with his business career.

The state hearing officer generally upheld the position taken by the school system. She stated that, although she accepted the unanimous testimony of professional witnesses that residential programming was indicated in the case at hand, she was convinced that such programming was required because of separate noneducational needs: ${ }^{140}$ the girl's behavior and emotional problems, and her home situation. In support of this position, the hearing officer cited the evaluating hospital's bifurcated description of the residential program it recommended, one which included both an academic component and a behavior modification-therapy component. ${ }^{141}$ The fact that these two components could be separately described served, for the hearing officer, as ample evidence that the modification-therapy component, and thus the overall program, was sought to address the girl's emotional needs.

139. 1982-83 Educ. HandicapPed L. ReP. (CRR) 504:302 (N.J. SEA 1983). Other administrative hearing officer decisions involving a similar dichotomy between educational and emotional or psychiatric needs include: In $r e$ P., 1982-83 Educ. Handicapped L. REP. (CRR) 504:148 (Conn. SEA 1983); Case No. 81-22, 1982-83 Educ. HandiCapped L. ReP. (CRR) 502:331 (Conn. SEA 1981); Case No. 80-24 (Jimmy F.), 1980-81 Educ. Handicapped L. ReP. (CRR) 502:109 (Conn. SEA 1980). At least one court has adopted an exclusionary approach in distinguishing between educational and medical needs. See McKenzie v. Jefferson, 566 F. Supp. 404 (D.D.C. 1983) (school district not required to pay for placement of emotionally handicapped child in private psychiatric hospital where primary purpose of placement was medical, placement was not made in support of special education program, and services received fell within medical services exception to definition of "related services"). For further discussion of the application of the medical services exception as it relates to the availability of psychotherapy, see part V B 2, infra. See also Stark, supra note 11, at 513-14.

140. 1982-83 Educ. Handicapped L. Rep. (CRR) 504:308, :309 (N.J. SEA 1983).

141. Id. at 504:308. 
The M.J.S. decision is marked by flawed logic and by insufficient factual analysis. To begin with, the scope of the holding is unclear. The hearing officer may have narrowly determined that the school system had no obligation to supply residential programming needed to meet a child's emotional needs where that programming was not simultaneously required to satisfy her educational needs to the extent required under the EAHCA's FAPE requirements. This holding would have been consistent with the facts at hand. The hearing officer did declare the school system's proposed locally available programming "appropriate," perhaps convinced that the girl would continue to perform at an average level academically, and that this was all that was needed to satisfy the FAPE standard. If this is indeed the case's narrow holding, however, it is unclear why characterization of the requested programming as meeting the girl's emotional needs was even necessary. A reviewing authority could not require of the school district additional services which provided more than the level of opportunity guaranteed pursuant to the FAPE standard, whether designed to meet the girl's educational or emotional needs.

Accordingly, a fair interpretation of the decision is that the hearing officer intended a broader holding declaring that school systems have no obligation to provide residential programming which addresses a child's educational needs if, at the same time, that programming responds to emotional or other noneducational needs-in essence, an adoption of the exclusionary approach. Unfortunately, the rationale behind this intended holding is obscure. The hearing officer may have defined educational need narrowly to exclude the need to acquire basic nonacademic skills, so that even though a child's emotional handicap gives rise to deficiencies in coping skills, a remedy for those deficiencies must be found outside the Act. ${ }^{142}$ This conclusion is question-

142. Many disputes regarding the definition of educational needs for purposes of the EAHCA involve disagreements between state agencies regarding overlapping responsibility for funding a particular child's placement in a residential setting. See, e.g., North v. District of Columbia Bd. of Educ., 471 F. Supp. 136 (D.D.C. 1979) (dispute regarding responsibilities of school board and social service agency); Parks v. Illinois Dep't of Mental Health \& Development Disabilities, 110 Ill. App. 3d 184, 441 N.E.2d 1209 (1982) (dispute regarding responsibility of state board of education and state mental health agency); D.S. v. Board of Educ., 88 N.J. Super. 592, 458 A.2d 129, cert. denied, 94 N.J. 529,468 A.2d 184 (1983) (dispute regarding responsibility of state and local boards of education).

For an extensive discussion of this problem, see Mooney \& Aronson, Solomon Revisited: Separating Educational and Other than Educational Needs in Special Education Placements, 14 CoNn. L. Rev. 531 (1982). Mooney and Aronson urge that a "but for" test be adopted in order to limit schools' responsibilities for residential placements which would be required because of emotional needs unrelated to the educational process. Id. at 552. There are two problems with this approach which closely parallel the problems with the M.J.S. decision itself. First, it is unclear under what circumstances emotional needs would be found to be "unrelated" to the educational process. If that term is used to suggest that schools need not fund residential placements where the school is required to provide a free appropriate public education, then the term complicates the inquiry, for a simpler determination of whether alternative programming would satisfy the Rowley standard should suffice. Alternatively, the proposal may suggest that, where compelling emotional needs can be demonstrated, a school would be relieved of any obligation to satisfy concomitant educational needs. While Congress specifically contemplated that local educational agencies could seek financial assistance from other state agencies in order to satisfy the obligations under EAHCA, Congress nevertheless envisioned that local educational agencies would remain ultimately responsible for provision of needed services. See S. REP. No. 168; 94th Cong., 1st Sess. 22, 24, reprinted in 1975 U.S. Code Cong. \& Ad. News 1446, 1448. While the Mooney and Aronson test might serve as a mechanism for allocating financial responsibility 
able in light of the previously cited evidence of Congress' intent that the schools assist handicapped children to acquire fundamental nonacademic skills in cases in which a particular disability prevents children from acquiring such skills through more informal contact with parents and other members of the community. ${ }^{143}$

Alternatively, the hearing officer may have defined educational needs narrowly to exclude those that only indirectly influence educational performance. Thus she may have believed that the child in question possessed adequate coping skills which rendered attention to her emotional needs unnecessary, even though those needs indirectly affected her ability to make meaningful progress toward instructional goals and objectives as required under the definition of a free appropriate public education. This view is similarly flawed. Congress' insistence that each handicapped child receive a free appropriate public education dominates the statute and its legislative history. ${ }^{144}$ The Congress authorized schools to employ a wide range of related services as tools to achieve this result, at least some of which work only indirectly to facilitate a handicapped child's attainment of his individual educational goals. ${ }^{145}$ Requiring schools to address underlying emotional needs which affect a child's educational achievement would be consistent with this strategy and would work in favor of Congress' paramount remedial objective. A narrower interpretation, which instead undercuts the attainment of that objective, should accordingly be rejected.

2. Inclusionary Approach. In light of the flaws evident in the exclusionary approach, it is not surprising that the alternative inclusionary approach now commands substantial judicial support. The courts' acceptance of this approach did not come easily, though, but can be traced over a period of several years.

The first step in the development of this approach occurred in North $v$. District of Columbia Board of Education. ${ }^{146}$ North involved efforts to procure residential programming for a seriously emotionally disturbed 16-year-old boy who also suffered from learning disabilities and epilepsy. An initial residential placement proved unsuccessful when the provider was unable to deal with his emotional and other problems. The school system refused to arrange another similar placement, arguing that it could provide an adequate day program to meet his educational needs, that residential programming was required only

between local educational agencies and other state and local agencies, at least for purposes of state budgetary or accounting practice, other more viable alternatives are probably available. See Stoppleworth, Mooney E Aronson Revisited: A Less than Solomon-Like Solution to the Problem of Residential Placement of Handicapped Children, 15 CoNN. L. REv. 757 (1983). In any event, their proposed approach cannot limit the ultimate responsibility of local agencies as a matter of federal law.

143. See supra notes 135-36.

144. See supra note 26; see also 20 U.S.C. $\$ 1401$ (C) (1976) (statement of purpose); S. ReP. No. 168, 94th Cong., 1st Sess. 9, reprinted in 1975 U.S. Code Cong. \& AD. News 1433; H.R. ReP. No. 332, 94th Cong., lst Sess. 7.

145. See infra note 176 and accompanying text (related services include psychological and counseling services).

146. 471 F. Supp. 136 (D.D.C. 1979). 
to satisfy his emotional needs, and that the appropriate social service agency, not the school system, should bear the attendant costs of such programming. The court rejected the school system's plea. The court stated that in some instances dilemmas of the sort presented would be better resolved through the instigation of neglect proceedings which would place the ultimate responsibility for a seriously impaired child's welfare with a social service agency. ${ }^{147}$ Where, however, as in the case at hand, such an approach would cause serious injury to the child, ${ }^{148}$ the federal education laws could be invoked. While observing that even if such laws were properly invoked, situations could arise in which emotional needs were dominant (cases in which, the court implied, the schools' responsibilities might differ), the court stated that no such determination was possible under the facts at hand since the child's emotional and educational needs were significantly intertwined. ${ }^{149}$ In such cases, the school system could be held accountable for supplying a child with needed residential programming consistent with the EAHCA's free appropriate public education guarantee. ${ }^{150}$

North thus represents an important first step toward the adoption of an inclusionary approach to defining the scope of educational needs. The court recognized that educational needs may overlap emotional needs in at least some instances and that, notwithstanding this fact, such educational needs must be addressed. The court's opinion, however, is flawed in certain respects. As in other cases, the scope of the court's rationale and holding is unclear. The court does not squarely state whether the child's emotional needs themselves give rise to educational needs which must carefully be attended, or whether emotional needs which indirectly affect a child's educational progress, as a result, attain derivative status as educational needs. The court also preserved the dichotomy between educational and emotional needs, and hinted that some sort of balancing process might be required to determine whether a child's educational or noneducational need for a particular service predominates. ${ }^{151}$ This statement accordingly suggests that an exclusionary approach might continue to be preferred, in future cases, at least in instances in which strong noneducational needs are found to exist.

The second step in the development of the inclusionary approach came two years later in Kruelle $v$. New Castle County School District. ${ }^{152}$ In Kruelle, the Third Circuit addressed the obligation of the affected school system to provide a residential program for a 13-year-old profoundly mentally retarded boy who also suffered from emotional problems. The school system had resisted

147. Id. at 140 .

148. The court noted that a neglect proceeding would itself have had a significant adverse effect on the child's course of treatment since his emotional problems would have been exacerbated by his perception that he had been abandoned by his parents. Id.

149. Id. at 141 .

150. Id. at 142 .

151. Id. at 141 .

152. 642 F.2d 687 (3d Cir. 1981). See also Christopher T. v. San Francisco Unified School Dist., 553 F. Supp. 1107,1119 (N.D. Cal. 1982) (following Kruelle approach). 
the parents' efforts to procure such programming, despite evidence of a successful prior residential placement and unsatisfactory local programming. The Third Circuit affirmed a district court decision which held for the parents after rejecting the view of a state hearing officer that the requested programming was more in the nature of parenting than education. ${ }^{153}$ While citing and purporting to rely upon North, the court framed the issue in a somewhat more helpful fashion by focusing directly upon whether residential placement "is part and parcel of 'specially designed instruction .. . to meet the unique needs of a handicapped child" "-that is, whether that placement is "a necessary predicate for learning" rather than unrelated to learning skills. ${ }^{154}$ The Third Circuit went on to justify its ultimate affirmance of the district court's decision by noting that residential programming was needed in order to provide the child in question with a greater degree of consistency in programming available as a result of full time care. ${ }^{155}$

Kruelle demonstrates important progress in the development of the inclusionary approach to defining educational needs for at least two reasons. First, the court squarely formulated the issue at bar in terms of the child's ability to learn, recognizing that the fact that requested services might simultaneously address emotional or custodial needs was largely irrelevant or at least of secondary importance. The decision therefore opened the way for abandonment of the educational/emotional needs dichotomy preserved in North. Second, the court articulated a more distinct rationale for its holding than had the North decision. The court appeared to recognize that custodial and residential support services could address a child's need for custodial care while simultaneously performing the critical educational function of reinforcing instruction of basic life skills.

The streamlined analysis foreshadowed in Kruelle emerged at last in fullblown form in Abrahamson $v$. Hershman. ${ }^{156}$ Abrahamson involved another seriously impaired child-a 16-year-old boy diagnosed as severely mentally retarded with behavior which was also described as autistic in character. Like the child in North, the child in Abrahamson had been previously placed unsuccessfully in a residential program. When residential placement subsequently became unavailable, the school system proposed that the child be placed in a day program operated through a consortium of several local public school systems; the school system did not include a residential component as part of his IEP. The district court held that such residential programming was necessary since the child required an extremely structured environment if he was not to regress from day to day, let alone have a chance to make any educational progress. ${ }^{157}$ The appellate court cited the district court as stating, however, that needed residential services might be provided through placement in

153. 642 F.2d 687.

154. Id. at 693-94.

155. Id. at 694 .

156. 701 F.2d 223 (1st Cir. 1983).

157. Id. at 226. 
a group home in conjunction with the local day program. ${ }^{158}$

The First Circuit affirmed. It reasoned that school systems have a paramount obligation to provide each handicapped child with a free appropriate public education, one which must be afforded, in certain instances, in institutional settings which necessarily provide ancillary custodial care. ${ }^{159}$ The First Circuit then observed that while foster care was not required to be provided, services which appeared to be custodial might, in appropriate cases, constitute a critical portion of a severely impaired child's educational program where that program was intended to help him master basic life skills. ${ }^{160}$ The appellate court also upheld the district court's conclusion that such services may, at the school district's option, be provided through placement in a group home facility adequately equipped to meet the child's needs. ${ }^{161}$

Abrahamson thus confirmed that the critical issue in determining whether a child's needs are educational in character is whether they relate to his ability to master pertinent skills. The court dismissed the defendant school district's proposed dichotomy between educational and custodial needs as unwarranted, suggesting that such dichotomies will no longer be relevant to analysis under the EAHCA. ${ }^{162}$ The court also provided an explicit rationale for its determination that the custodial care in question was educational in nature, emphasizing the fact that such custodial care and residential services themselves perform an educational function for a child who is endeavoring to master basic self-care skills. Significantly, however, the court appeared to question an alternative suggestion, noted above, that custodial needs deserve derivative status as educational needs where, if left unattended, the child in question would be denied a free appropriate public education. ${ }^{163}$ Other deci-

158. Id.

159. Id. at 227 .

160. Id. at 228 .

161. Id. at 229 .

162. Id. at 228-29.

163. This inference may be drawn from a brief comment on the availability of residential programming for children who suffer from poor home situations.

This is not to say that the Act requires a local school committee to support a handicapped child in a residential program simply to remedy a poor home setting or to make up for some other deficit not covered by the Act. It is not the responsiblity of local officials under the Act to finance foster care as such: other resources must be looked to. . . . Congress did not intend to burden local school committees with providing all social services to all handicapped children.

Id. at 227-28. The court's statement might be seen to relieve schools of responsibility for providing custodial services to children who are in fact receiving an appropriate education in the local setting but who would also benefit from residential placement in order to escape difficulties at home. See, e.g., In re Wellesley Pub. Schools, 1982-83 Educ. Handicapped L. ReP. (CRR) 504:268 (Mass. SEA 1983); In re Joseph K., 1982-83 Educ. Handicapped L. ReP. (CRR) 502:133 (Ga. SEA 1980). The statement could also be interpreted in a broader fashion as limiting the responsibility of schools to provide some type of residential programming even where the combined force of a child's handicap and poor home setting precludes his receiving an appropriate education in the absence of such services. Federal regulations under section 504 of the Rehabilitation Act of 1973, referred to in the commentary to the EAHCA regulations described supra note 134 , are similarly ambiguous on this point. See 34 C.F.R. $\$ 104.33$ app. A (1983) (regulation requiring that residential placements be provided at no cost where necessary to provide a free appropriate education to a handicapped individual, interpreted in commentary as inapplicable " $[w]$ hen residential care is necessitated not by the student's handicap, but by factors such as the student's home conditions"). 
sionmakers have nevertheless adopted a contrary view, determining that residential placement should be afforded where necessary to address children's educational needs, even in several cases in which those needs were exacerbated by poor home situations. ${ }^{164}$

Finally, the court resolved a question left unclear under the EAHCA regulations previously discussed, ${ }^{165}$ by determining that custodial services provided in a group home, rather than an institution, were as necessary and appropriate in addressing a child's educational needs as similar services available in a more restrictive institutional setting. ${ }^{166}$ This result is likely to spur increased reliance on community-based residential placement as an adjunct to private day care programs, a result which may foster cost-effective delivery of services in a beneficial, more fully integrated environment.

Abrahamson should not be interpreted as requiring school districts to routinely assume responsibilities for the complete range of handicapped children's instructional, custodial, emotional, and medical needs, however. The scope of educational needs is only one of several questions which must be answered in determining the mix of programming to be afforded a given child. While an expansive, inclusionary view of educational needs lies at the core of the Act's programming requirements, other aspects of the EAHCA effectively limit the impact that might otherwise result from that interpretation. Thus, however broadly a child's needs may be defined, school districts are only obliged to respond to those needs at the level and to the extent earlier described in parts II and III. Moreover, Congress has carved out a categorical medical services exception as part of its definition of "related services," 167 thus intervening to relieve school districts of possible obligations to address medical needs which indirectly affect a child's educational performance by restricting the types of services that might be used to do so.

The cases discussed above demonstrate, once again, that courts and quasijudicial decisionmakers faced with problems of construction under the

164. See Doe v. Anrig, 692 F.2d 800, 808 (1st Cir. 1982) (while governing consideration is not the needs of the parents but of the child, child should not be placed in possibly hostile home environment which would adversely affect his educational development); In $r e$ Los Angeles Unified School Dist., 1981-82 Educ. Handicapped L. ReP. (CRR) 502:364 (Cal. SEA 1981) (where emotional problems, home problems, and educational problems intertwined, residential placement would be required); In re East Side Union High School Dist., 1981-82 Educ. Handicapped L. REP. (CRR) 502:374 (Cal. SEA 1981) (although child's nonschool social environment is a major cause of her school problems, residential placement required because all that matters is that her condition makes her unable to learn); Case No. 81-14, 1982-83 Educ. Handicapped L. Rep. (CRR) 502:292 (Conn. SEA 1981) (residential placement required where student's academic progress had been minimal and parent was unwilling or unable to cope with student's presence at home). This position seems well founded for at least two reasons. First, the presence of a severely handicapped child can itself add significant stress to the home environment. Efforts to distinguish between the effects of a child's handicapping condition and the existence of independent problems in the home environment are, therefore, often neither theoretically nor practically justified. Second, the whole thrust of EAHCA appears to be to ensure that handicapped children receive an adequate education whatever the nature or source of their handicap. Only an approach which takes the child as he is and addresses his needs as they stand can accomplish this objective.

165. See supra text accompanying notes 137-38.

166. Abrahamson, 701 F.2d at 229 .

167. 20 U.S.C. $\$ 1401$ (17) (1982). 
EAHCA have turned to the concept of equal educational opportunity for guidance. Because this concept is an ambiguous one, competing lines of interpretation have developed. Nevertheless, it is possible to evaluate such competing views to determine which comports more closely with the policies of the Act-in this case, an inclusionary approach to defining the scope of educational needs which fall within its purview. At the same time, the question of scope cannot be viewed in isolation. Instead, the use of a broadly defined notion of equal educational opportunity in this context is coupled with distinct, more narrow applications of that concept in related contexts, to describe the obligations of school districts to provide educational programming under the Act.

\section{V \\ Availability of Medical Services}

Even assuming the adoption of a broad definition of educational needs for purposes of the Act, an additional question frequently arises concerning the availability of certain types of nontraditional services of a medical nature needed to permit particular handicapped children to make even minimal progress toward appropriate goals and objectives. Parents have requested such services in a variety of situations. For example, they have urged schools to provide clean intermittent catheterization (CIC) to students paralyzed from the waist down who need assistance in emptying their bladders during school hours in order to avoid the risk of increased internal infections while enrolled in regular classes appropriate to their intellectual needs. ${ }^{168}$ Parents have also sought intensive psychotherapeutic services which can only be provided through the supervision of a medically licensed psychiatrist. ${ }^{169}$ Schools hesitate to provide such services for a variety of reasons including concern

168. Clean intermittent catheterization (CIC) may be defined as follows:

CIC is a very simple procedure which can be performed within five minutes. The catheter is washed with soap and water; the urethral area is wiped clean; the catheter is introduced approximately one and one-half inches into the urethra and the bladder contents drained; the catheter is withdrawn; and the amount of urine collected is measured and noted. The procedure can be taught to anyone after a training session of approximately thirty minutes, and it need not be performed by a doctor or nurse. Currently, [plaintiff's child] is catheterized at home by her parents, teenage sibling, and babysitter. However when [the child] is 8 or 9 years old, she will be able to perform CIC upon herself.

Tatro v. Texas, 625 F.2d 557, 559 n.3 (5th Cir. 1980) on remand, 516 F. Supp. 968 (N.D. Tex. 1981), affd, 703 F.2d 828 (5th Cir. 1983), aff' in part, rev'd in part sub nom Irving Indep. School Dist. v. Tatro, 104 S. Ct. 3371 (1984).

169. The term "psychotherapy" has generally been used to describe diverse forms of intensive psychological intervention. See, e.g., The Encyclopedia Dictionary of Psychology 551 (Harre \& Lamb eds. 1983) (defining psychotherapy as "treatment of emotional and personality difficulties by psychological means"). Alternatively, the term has been seen to refer to treatment of "[a]ny form of treatment for mental illnesses, behavioral maladaptations, and/or other problems that are assumed to be of an emotional nature, in which a trained person deliberately establishes a professional relationship with a patient for the purpose of removing, modifying, or retarding existing symptoms or attenuating or reversing disturbed patterns of behavior, and of promoting positive personality growth and development." Psychiatric Dictionary 519 (R. Campbell, 5th ed. 1981). Professionals disagree concerning a more precise definition. See. Psychotherapy as a "Related Service," 1981-82 Educ. Handicapped L. ReP. (CRR) AC15, 16, 19, 23 (Supp. 60, Nov. 13, 1981). 
regarding anticipated high costs ${ }^{170}$ and doubts concerning how provision of medical services fit within their ever-expanding institutional mission. Many schools have accordingly interpreted language in the Act as largely exempting them from any obligation to provide such "medical" services. ${ }^{171}$

Disputes regarding the availability of medical services have not generally been understood to involve uncertainty concerning the application of the concept of equal education opportunity. However, careful examination suggests that, as in the two contexts previously considered, disagreements concerning the interpretation to be accorded the EAHCA's medical services exception rest, in part, on differing views concerning precisely that point.

Resolution of such disputes requires a determination of whether Congress intended to remove all forms of nonevaluative, nondiagnostic medical services from its definition of related services available under the Act, ${ }^{172}$ or whether it desired to craft a medical services exception subject to two partial limitations. Schools have urged that the medical services exception is a comprehensive one, designed to codify traditional practices. As noted above, nonhandicapped children have historically received an educational opportunity embodied in a common or diversified curriculum of instructional services. Through the Act, Congress required certain additional, related services to be made available. ${ }^{173}$ With respect to medical services, however, Congress expressly declined to vary from the norm. Accordingly, it is contended, the EAHCA imposes no obligation to provide such services.

A competing argument might well be formulated in equal educational opportunity terms. While the medical services exception may be broad, it is limited in at least two respects, and it thus is better characterized as a partial exception. First, nonhandicapped children should not be denied de minimus medical services comparable to those provided to their nonhandicapped peers. Second, where Congress has explicitly indicated that certain other types of services (including psychological and counseling services) must be made available in order to ensure that handicapped children receive an equal opportunity to be educated in accordance with their unique needs, ${ }^{174}$ the medical services exception should be interpreted consistent with, rather than in derogation of, that explicit requirement.

Section A reviews statutory and regulatory provisions bearing on the availability of medical services. Section B discusses the courts' interpretation of the medical services proviso in two problematic factual contexts-when parents request that their child be provided with $\mathrm{CIC}$, and when parents demand that psychotherapy be provided at public expense. The analysis will conclude that the Supreme Court's recent Tatro decision regarding the availability of

170. See McKenzie v. Jefferson, 566 F. Supp. 404, 407 (D.D.C. 1983) (costs of outpatient psychiatric treatment approximately $\$ 23,000$ per year, cost of inpatient treatment approximately $\$ 60,000$ per year); see also Stark, supra note 11, at 516-18.

171. See infra text at note 175 for pertinent statutory text.

172. 20 U.S.C. $\$ 1401(17)(1982)$.

173. Id.

174. Id. 
$\mathrm{CIC}$ and the decisions of the majority of lower courts concerning the provision of psychotherapy are consistent with the second of the two interpretations proposed above, that which recognizes two limitations on the EAHCA's medical services exception in the interest of assuring a more broadly defined equal educational opportunity.

\section{A. Statutory and Regulatory Text}

The statutory text provides important, but cryptic, guidance. The definition of "related services" states that in "appropriate" cases the following services must be provided as part of a free appropriate public education:

[S]uch developmental, corrective, and other supportive services (including speech pathology and audiology, psychological services, physical and occupational therapy, recreation, and medical and counseling services, except that such medical services shall be for diagnostic and evaluation purposes only) as may be required to assist a handicapped child to benefit from special education. ${ }^{175}$

This language is important both for what it gives and for what it takes away. It expressly endorses the use of corrective and supportive services which are not themselves educational in nature where required to ensure that a handicapped child's educational needs are met. At the same time the statute expressly restricts the types of medical services to be provided.

This critical exception is framed in functional terms. By specifying that medical services must be provided for diagnostic and evaluative purposes, the statute implicitly suggests provision of such services for certain other purposes is not required. Obviously excluded are provision of services designed to provide medical treatment to handicapped children, in an effort to reduce the effect of their disabling conditions, and services to afford requisite life support. Congress therefore appears to accomplish its probable objective of ensuring that general responsibility for handicapped children's medical requirements not be transferred from parents and other providers to the schools. This interpretation simultaneously assumes that the reference to diagnostic and evaluative purposes is not designed as Congress' own embodiment of a de minimis exception to a more comprehensive limitation on the availability of medical services. Consequently, the possibility remains of interpreting this provision to require the provision of de minimis medical services consistent with a narrow application of the concept of equal educational opportunity such as described above.

The EAHCA's legislative history provides limited additional guidance concerning the appropriate interpretation of the medical services proviso. The Senate bill, which served as the principal vehicle for discussion during the early stages of the EAHCA's development, included a limited list of related services and made no reference to the availability of medical services. ${ }^{176}$ The

175. 20 U.S.C. $\$ 1401(17)$ (1982) (emphasis added).

176. See S. REP. No. 168, 94th Cong., 1st Sess. 62 (1975) (“' 'related services' means transportation and developmental, corrective, and other supportive services (including, but not limited to, speech pathology and audiology, psychological services, counseling services, physical and occupational therapy, and recreation) as required to assist a handicapped child to benefit from special edu- 
bill reported by the House Education and Labor Committee contained the statute's current language, accompanied by a noncommital textual summary of the revised definition. ${ }^{177}$ The Conference Committee merely noted the discrepancy between the House and Senate versions of the legislation while acceding to the inclusion of the medical services proviso that was in the House version. ${ }^{178}$

The EAHCA regulations issued in the wake of enactment carefully defined certain of the terms included in the statutory text. These rules included certain narrowly circumscribed "medical services" within the scope of available "related services"- - "services provided by a licensed physician to determine a child's medically related handicapping condition which results in the child's need for special education and related services." 179 The regulations also stated that "related services" include "school health services," defined as "services provided by a qualified school nurse or other qualified person." 180 No commentary was provided to justify the latter provision, only a brief observation that the related services definition included in the final regulations went beyond the formulation originally published in the proposed text. ${ }^{181}$

EAHCA regulations currently in force thus specify that two classes of medical services are to be provided, where necessary, pursuant to the EAHCA: diagnostic and evaluative services, expressly addressed by the statute, and school health services, an invention of the regulators. Unfortunately, no justification is included in support of the later school health services requirement. One may infer from the first of the subsidiary definitions just quoted that the regulators interpreted the term "medical services" to refer to services provided by a licensed doctor, but not services afforded by other licensed professionals or by laypersons. Accordingly, the services of nurses or other persons referred to in the "school health services" definition would not be regarded as "medical services" but instead required as another type of service authorized by the more general catchall portion of the related services provision. This conclusion is confirmed both by a subsequent interpretative ruling regarding the availability of clean intermittent catherization ${ }^{182}$ and by the approach adopted in the ill-fated 1982 regulatory revisions addressing the general avail-

cation, and includes the early identification and assessment of handicapping conditions in children and provision of services to such children").

177. See H.R. ReP. No. 332, 94th Cong., 1st Sess. $42-43$ (1975) (language of bill); id. at 27 ("related services" include "recreation, and medical and counseling services").

178. See S. Rep. No. 455, 94th Cong., 1st Sess. 30 (1975).

179. 34 C.F.R. \& 300.13(b)(4) (1984).

180. Id. $\S 300.13(\mathrm{~b})(10)$.

181. 42 Fed. Reg. 42,505 (1977).

182. See 46 Fed. Reg. 4912 (1981) (interpretative ruling regarding the availability of CIC); id. at 25,614 (indefinitely postponing implementation of interpretive ruling). The interpretative ruling concluded that CIC should be provided, consistent with prevailing judicial precedent, because: CIC could be performed by unlicensed persons with minimal training; such services could be covered by the reference to "supportive services" which appeared elsewhere in the related services definition; and such services permitted children to be placed in the least restrictive environment rather than consigned to home study. 
ability of medical services under the Act. ${ }^{183}$ The merits of this approach are explored more readily after a brief exposition of relevant case law.

\section{B. Judicial Response}

A substantial body of case law is beginning to develop concerning the scope of the EAHCA's related services provision and the medical services proviso. ${ }^{184}$ Discussion of the evolving doctrine is advanced best by concentrating upon the two fact patterns receiving the most sustained judicial attentionchallenges involving the availability of clean intermittent catheterization needed by children with spina bifida and disputes concerning the provision of psychotherapy.

\section{Clean Intermittent Catheterization. The ongoing litigation in the Tatro case} provides an obvious focal point for examination of the availability of CIC, for it is this case which the Supreme Court recently chose as its own vehicle for exploring the scope of the EAHCA's medical services proviso. ${ }^{185}$ Amber Tatro's story, like Amy Rowley's, is now well known. Amber was born with spina bifida and, as a result of that birth defect, suffered from orthopedic and speech impediments and a neurogenic bladder. ${ }^{186}$ When Amber was 3 years

183. See 47 Fed. Reg. 33,836 (1982) (proposed amendments to EAHCA regulations). The proposed regulations would have deleted the school health services portion of the earlier related services definition because no reference to such services was included in the statutory definition. Id. at 33,838 . Any other obligation any agency might have to handicapped children in making available the same services provided to nonhandicapped children would have been unaffected by this change, however. Id. at 33,854 (proposed 34 C.F.R. $\$ 300.13$ ). See also id. at 33,839. Moreover, the regulatory preamble specifically stated that these changes were not designed to "categorically preclude the provision of [CIC]"; instead decisions on whether that service was required would be made by public agencies on an individualized basis. $I d$. at 33,838 .

The proposed regulations would also have modified the existing medical services definition in several other pertinent ways. First, the reference to licensed physicians previously included in the regulatory "medical services" definition was replaced with a broader reference to "services relating to the practice of medicine." Id. at 38,846 (proposed 34 C.F.R. $\$ 300.4(10)$ (i)). Second, the regulations stated that public agencies were not required to provide life sustaining procedures that: (1) could be provided outside the normal school day, (2) must be performed under sterile conditions, (3) must be administered by specially trained, licensed health care professionals, or (4) entailed a significant risk of illness or more than minimal injury to the child. Id. Neither were schools required to provide surgical procedures, medication or the administration of medication, or individually prescribed devices such as eyeglasses. Id.

The proposed regulations were later withdrawn in large part. See EHLR Round-Up: House Hearings on Proposed Regulations, 1982-83 Educ. Handicapped L. Rep. (CRR) SA-1 1 (Supp. 81, Oct. 1, 1982).

184. See, e.g., Department of Educ. v. Katherine D., 727 F.2d 809, 813 (9th Cir. 1983) (maintenance of tracheotomy tube is related service); Espino v. Besteiro, 520 F. Supp. 905, 911 (S.D. Tex. 1981), rev'd on other grounds, 708 F.2d 1002 (5th Cir. 1983) (air conditioning is related service).

185. The Tatro litigation endured for more than four years. See 481 F. Supp. 1224 (N.D. Tex. 1979), vacated and remanded, 625 F.2d 557 (5th Cir. 1980), on remand, 516 F. Supp. 968 (N.D. Tex. 1981), affd, 703 F.2d 823 (5th Cir. 1983), affd in part, rev'd in part sub nom. Irving Indep. School Dist. v. Tatro, 104 S. Ct. 3371 (1984). The Tatro litigation is discussed in Note, $A$ Confusion of Rights and Remedies: Tatro v. Texas, 14 ConN. L. Rev. 585 (1982). For other cases involving CIC, see Tokarcik v. Forest Hills School Dist., 665 F.2d 443 (3d Cir. 1981); Hairston v. Drosick, 423 F. Supp. 180 (S.D. W. Va. 1976) (decided under section 504 of the Rehabilitation Act of 1973); $c f$. Department of Educ. v. Katherine D., 727 F.2d 809 (9th Cir. 1983) (availability of emergency services required by child with cerebral palsy whose tracheotomy tube might be dislodged).

186. Irving Indep. School Dist. v. Tatro, 104 S. Ct. 3371,3374 (1984). 
old, her parents requested that she be permitted to attend the Irving Independent School District's early childhood development program. The school district did not refuse her admission but declined to provide CIC needed by Amber if she was to be present throughout the half-day program. The Tatros brought an action for injunctive relief in federal district court under the EAHCA and section 504 of the Rehabilitation Act of 1973.187

The court rebuffed the Tatros when it granted defendants' motion to dismiss the EAHCA claim. ${ }^{188}$ The district court reasoned that the related services required under the Act were of two types: (1) transportation and (2) supportive services required to assist the child to benefit from special education. ${ }^{189}$ Because the latter category "might, if read literally, require schools to furnish every necessary life support system," the court adopted a narrowing gloss by stating that "to be related in the statutory sense, the service requirement must arise from the effort to educate." 190 The court also concluded that only those "school health services" which satisfied this restrictive interpretation of "related services" could be required. ${ }^{191}$ The court did not, however, attempt to probe, in any detail, the significance of the medical services exclusion itself. 192

The Fifth Circuit rejected this restrictive reading. ${ }^{193}$ The appellate court concluded that CIC was a supportive service for purposes of the related services definition. ${ }^{194}$ However, the panel believed that the Act contained its own limitations which would ensure that school systems could not be required to supply every extensive life support procedure a child might need. ${ }^{195}$ The court also stressed the importance of the Act's least restrictive environment mandate, ${ }^{196}$ stating that a determination concerning the availability of CIC should take into account the fact that a child denied such services would likely be consigned to educationally inappropriate programs of homebound instruc-

187. Id. at 3374-75.

188. A claim was also asserted under section 504 of the Rehabilitation Act of 1973. The lower court rejected that claim using reasoning similar to that with which it disposed of the EAHCA cause of action. 481 F. Supp. 1224, 1229 (N.D. Tex. 1981). The Court of Appeals reversed on this point as well, concluding that $\mathrm{CIC}$ was the sort of minimal reasonable accomodation required by that statute. 625 F.2d 557, 564-65 (5th Cir. 1980). Six members of the Supreme Court ultimately concluded that the Tatros were not entitled to relief under section 504, and attendant attorneys' fees, since "relief [was] available under the Education of the Handicapped Act to remedy a denial of educational services." 104 S. Ct. at 3379. See also Smith v. Robinson, 104 S. Ct. 3457 (1984) (holding that parents are not entitled to receive attorneys' fees under $\S 505$ of the Rehabilitation Act where a remedy is available under the EAHCA but no provision is made under that statute for award of attorneys' fees).

189. 481 F. Supp. at 1227.

190. Id.

191. Id. at 1228 .

192. Id.

193. 625 F.2d 557 (5th Cir. 1980).

194. Id. at 562 .

195. Id. at 562-63. The court cited three such limitations: (1) the requirement that the affected child be handicapped and require special education; (2) the necessity that the life support system aid the child in benefiting from special education, which the court believed limited the required services to those needed during school hours; and (3) the rule that the life support system be one which a nurse or other qualified person could provide.

196. Id. at 563 . 
tion. ${ }^{197}$ The case was then vacated and remanded for necessary additional proceedings.

In Tatro II, the district court proceeded to inquire whether, under Texas law, CIC was a medical service which could only be provided by a physician or whether it fell within the scope of the regulatory provision relating to "school health services" capable of provision by a qualified school nurse or other qualified person. ${ }^{198}$ With the aid of briefs from state and local medical associations, the court concluded that a qualified individual acting pursuant to a physician's prescription and under a physician's supervision could provide CIC. ${ }^{199}$ The school district appealed and a different panel of the Fifth Circuit affirmed. ${ }^{200}$ While expressing reservations about the merits of the earlier panel's decision, the court nevertheless concluded that the analysis included in Tatro $I$ represented a reasonable reading of a "delphic statute." 201 The second panel also upheld the trial court's reading of Texas law concerning the proper practice of medicine, as well as the application of that law to the facts at hand. ${ }^{202}$

A unanimous Supreme Court affirmed on EAHCA grounds. ${ }^{203}$ The Court held that CIC is a supportive service which was needed by Amber Tatro to allow her to benefit from special education. ${ }^{204}$ It further determined that the medical services exception did not apply. ${ }^{205}$ In reaching this conclusion, the Court relied heavily upon an earlier interpretative ruling of CIC which had been issued by the United States Department of Education, ${ }^{206}$ a ruling which the Court believed was entitled to deference as a reasonable interpretation of congressional intent. ${ }^{207}$ The Court stated that the Secretary of Education "could reasonably have concluded that [the medical services exception] was designed to spare schools from an obligation to provide a service that might well prove unduly expensive and beyond the range of their competence." 208 The Court then explained that the provision of CIC imposed no such cost burden, and that the obligation of schools to make CIC and other school health services available merely required districts to continue to provide limited school nursing services simlar to those traditionally afforded all chil-

197. Id.

198. 516 F. Supp. 968 (N.D. Tex. 1981).

199. Id. at 975-77.

200. 703 F.2d 823 (5th Cir. 1983).

201. Id. at 826 .

202. Id. at 827-29. The court also rejected arguments that Amber did not, in fact, require CIC in order to attend the district's half-day early childhood program, and that intervening interpretations required a reversal of its earlier determination concerning the merits of plaintiffs claim under section 504 thereby relieving the school district of liability for attorneys' fees under that provision. Id. at 831-32.

203. 104 S. Ct. 3371 (1984). Justices Brennan, Marshall, and Stevens dissented from the majority's determination that the Tatros could not be awarded attorneys' fees. Id. at 3379-80.

204. Id. at 3377.

205. Id.

206. See supra note 182.

207. 104 S. Ct. 3371,3377 (1984).

208. Id. at 3378 . 
dren. ${ }^{209}$ The Court rejected the school district's argument that CIC should be regarded as a medical service since it could only be provided pursuant to a physician's prescription under Texas law. Instead, the Court noted that minor medical services, such as the administration of medicine, were routinely provided to nonhandicapped children, concluding that "[i]t would be strange indeed if Congress, in attempting to extend special services to handicapped children, were unwilling to guarantee them services of a kind that are routinely provided to the nonhandicapped."210 Finally, the Court cited four restrictions which it believed moderated the burdens upon school districts that might flow from the application of its de minimus limitation on the medical services exception: (1) related services such as CIC need only be provided to handicapped children in need of special education; (2) only services necessary to aid a child to benefit from such education need be supplied, not services that might be provided outside the school day; (3) only services that may be performed by a nurse or a layperson must be provided, not those which require the assistance of a physician; and (4) only de minimis medical services, not equipment, must be made available. ${ }^{211}$

The Court's decision in Tatro is a sound, well-reasoned one. The case's outcome reflected the balance of equities involved. Amber Tatro's situation was much more emotionally compelling than Amy Rowley's. A determination that CIC is a related service was required if Amber was to receive an education at all appropriate to her social and intellectual abilities, rather than being consigned to the plainly inadequate alternatives of home study or placement in a private setting catering to children with much more severe multiple impairments. Few countervailing considerations favored the school district. Provision of CIC was neither disruptive nor costly, especially when compared to the expensive placement alternatives just described. It is hardly surprising, therefore, that the Court would conclude that the Tatros should prevail.

The decision is also carefully grounded and explained. The Court made no bones about its reliance upon equal educational opportunity principles as a central basis for its decision. It disposed of the school district's proposed interpretation of the medical services exception in a single paragraph, stressing repeatedly that only a "strange" or "anomolous" reading would attribute to Congress a desire to deny handicapped children access to services available to their nonhandicapped peers. ${ }^{212}$ The Court might have gone even further in bolstering its justification, for the EAHCA's legislative history plainly supports this position. ${ }^{213}$

209. Id .

210. Id.

211. Id. at 3379 .

212. Id. at $3377-78$.

213. See, e.g., S. ReP. No. 168, 94th Cong., 1st Sess. 12 (1975) ("The Committee points out in addition that a handicapped child has a right to receive all services normally provided a nonhandicapped child enrolled in a public elementary . . . school. Thus, he or she has a right to physical education services, health screening, transportation services and all other services which are provided to all children within the school system, and a right to as many options in curricula as are available to all children.") (emphasis added). 
This approach provides an important theoretical underpinning absent from existing regulations and prior case law. The Education Department's "school health services" regulations ${ }^{214}$ no longer appear rooted in an arbitrary distinction between two classes of medically trained and licensed personnel (doctors and nurses), each of whom would appear to provide medical services, that is, services designed to maintain health and prevent, alleviate, or cure disease. Instead, the requirement that certain services be provided through school nurses is explained in terms of historical tradition and the probable intention of Congress to preserve that tradition for all children. The Fifth Circuit's earlier determination that "school health services" include only those medical services that must unavoidably be provided during the school day 215 is similarly illuminated. No comparable restriction has been applied to other types of related services, such as counseling, which might well be provided outside of traditional school hours; it is therefore evident that this limiting gloss does not stem from the terms of the "related service" definition which specify that such services must be "required to assist" a handicapped child to benefit from special education. The Court's approach makes plain that the limitation flows inevitably from the fundamental premise that handicapped children should receive school health services comparable to those enjoyed by others. Since nonhandicapped children only receive school medical services that cannot be provided in off hours, that same restriction should apply to their handicapped peers.

In addition to providing a useful theoretical perspective, the Court offered needed practical guidance. Two questions are likely to emerge in the wake of the Tatro decision: (1) what are the obligations of school districts which do not now employ school nurses? and (2) what range of school health services other than CIC need be supplied? Tatro touches on each of these questions in at least a preliminary fashion.

It is plain that school districts which provide school health services must open those services to both handicapped and nonhandicapped children. Irving Independent School District apparently authorized school nurses to dispense oral medications and administer emergency injections in accordance with a physician's prescription. ${ }^{216}$ It is therefore obliged to accommodate the needs of handicapped students for simlar, minimal medical assistance. Given these facts, the Court's holding might be viewed as a narrow one, applicable only to schools currently providing school health services through school nurses. The Court's logic would seem, however, to dictate a broader result. The Court did not rest its decision solely on Irving Independent School District's past practices. Instead, it relied upon federal regulations which had reasonably concluded that Congress had designed the medical services exception to limit school district obligations to provide costly hospital and physician services, not to supplant the traditional system of retaining school nurses on

214. See supra note 182 .

215. See supra note 195.

216. 104 S. Ct. 3371,3378 (1984). 
school district staffs. Read in this restrictive fashion, the medical services proviso does not limit the authority of federal regulators to require all school districts to supply CIC and other supportive school health services, whether those districts have done so in the past or not. The Court thus ensured that a nationwide standard would continue to govern the minimum range of services available under the EAHCA, rather than limiting its equal educational opportunity equation to analysis of the historical practices of individual school districts. Whether districts will meet their obligations by hiring school nurses, contracting for visiting nurse assistance, or training other personnel to meet necessary requirements will be up to them.

The range of de minimis school health services that must be provided in the wake of Tatro is less clear. Tatro recognizes that at least those services that may only be provided by licensed physicians generally fall within the medical services exception and need not be supplied under the EAHCA. Thus, it is clear that schools need not pay the cost of corrective surgery or other similar procedures. At the same time, Tatro indicates that certain de minimis medical services that can be performed by registered nurses or other qualified personnel must be provided. Schools will be obliged to expand their current medical service offerings, increasing both the types of medical services available (providing CIC as well as dispensing medication), and the terms on which those services are offered (supplying routine as well as emergency assistance). It is obvious that state licensing laws and attendant restrictions on nurses' authority and duties will serve as an outer limit on schools' obligations under the Court's ruling, ${ }^{217}$ and that, in any event, federal regulators are likely to defer to such authority. ${ }^{218}$ School districts' responsibilities may well fall somewhat short of offering a full range of services that a nurse is capable of providing, however. As previously discussed, ${ }^{219}$ the rationale of the Tatro decision was not simply that licensed doctors, and not nurses, are providers of medical services. Instead, the decision recognized that a certain class of nursing services traditionally had been offered nonhandicapped children, and that a comparable set of de minimis services should thus be available to handicapped children under the EAHCA. It therefore follows that only certain nursing services need be provided by local educational agencies. Which services fall within this de minimis class will likely stir continuing debate. The Court's analysis in Tatro suggests, however, that only those medical services which can safely be performed in the school environment, with minimal time, staff, expense, and equipment, should be seen to fall within the Tatro rule. Other services, such as the performance of kidney dialysis, cannot fairly be characterized as de minimis in character. Accordingly, they should be

217. Id. at 3379. ("school nursing services must be provided only if they can be performed by a nurse or other qualified person").

218. See, e.g., 47 Fed. Reg. 33,839 (1982) (guideline accompanying proposed regulatory amendment specified that public agencies may look to standards, opinions, and other determinations of State medical licensing authorities in determining if certain services are medical services within the meaning of the EAHCA).

219. See supra text accompanying note 214. 
regarded as falling within the statutory medical services exception, even if they might be provided by a nurse or other trained person acting under a physician's direction.

In sum, the Supreme Court's approach in Tatro both parallels and differs from its approach in Rowley. The equal educational opportunity theme underlies both decisions. Although Rowley had defined the level and extent of services under the Act in terms of a restrained "some benefit" version of that theme, Tatro reflects a more expansive interpretation, appropriate to its subtly different subject matter. While considerations of justiciability and cost limited the Court's choice of standard in the earlier case, similar constraints did not prevent its adoption in Tatro of a construction which required minimal expenditure of school district funds and which necessitated only limited, nationwide comparison of the types of services afforded handicapped and nonhandicapped children.

2. Psychotherapy. While many schools have agreed to provide CIC in response to pressure from federal administrative agencies and unanimous court decisions, schools have more slowly and reluctantly conceded a possible obligation to provide intensive psychotherapy when needed by children who are seriously emotionally or mentally impaired. Although psychotherapeutic services at times are offered by trained social workers and psychologists, they may also be offered by psychiatrists who are licensed physicians, or by social workers and psychologists operating under a physician's direction. At least arguably, those intensive services offered by or under the supervision of a psychiatrist may be characterized as medical in character. In the wake of Tatro, a dearth of definitive regulatory guidance concerning the availability of such services and an emerging split in judicial opinions on this issue is likely to result in growing uncertainty regarding the schools' obligations to provide such services at no cost.

Consistent with the EAHCA's statutory text, ${ }^{220}$ United States Department of Education regulations specify that certain counseling and psychological services must be provided. The regulations define counseling services by reference to possible service providers, stating that such services are those "provided by qualified social workers, psychologists, guidance counselors, or other qualified personnel."'221 "Psychological services," in turn, refers to the performance of several specific diagnostic, interpretive, and counseling functions. ${ }^{222}$ Because the regulations do not expressly include psychiatrists among the listed providers of counseling services, they may imply that schools are not obliged to supply psychotherapeutic services only available from such persons or services provided under their direction. The Department of Edu-

220. 20 U.S.C. $\$ 1401(17)(1982)$.

221. See 34 C.F.R. $\$ 300.13(b)(2)$ (1984).

222. Id. at $\S 300.13(\mathrm{~b})(8)$ : 
cation's more recent pronouncements have been equivocal on this point. ${ }^{223}$

The weight of judicial authority interprets the EAHCA to require the provision of psychotherapy in appropriate cases. In re " $A$ " Family is an early representative case which adopts this view. ${ }^{224}$ The case involved a family of a seriously emotionally disturbed, schizophrenic boy which requested the provision of intensive psychiatric services for the boy as part of a private residential program. The plaintiffs asked the Montana Supreme Court to determine whether such services were medical services, which fell beyond the scope of the definition of related services just discussed, or psychological services, which are listed without qualification as an available service within the terms of the EAHCA. After consulting a standard dictionary, the court concluded that "psychotherapy" referred to "treatment of [a] mental or emotional disorder or of related bodily ills by psychological means."225 Since the court believed such psychotherapeutic services were expressly included within the phrase "psychological services," the court gave no further consideration to the application of the medical services proviso. ${ }^{226}$

A recent decision of the federal district court for the Northern District of Illinois took an opposing position. Darlene L. v. Illinois State Board of Education $^{227}$ involved a child diagnosed as having a severe behavioral disorder. Local school officials and the child's parents argued that she needed placement in a residential program. However, the state administrative agency charged with review of private placements refused to authorize payment for

"Psychological services" include:

(i) Administering psychological and educational tests, and other assessment procedures;

(ii) Interpreting assessment results;

(iii) Obtaining, integrating, and interpreting information about child behavior and conditions relating to learning;

(iv) Consulting with other staff members in planning school programs to meet the special needs of children as indicated by psychological tests, interviews, and behavioral evaluation; and

(v) Planning and managing a program of psychological services, including psychological counseling for children and parents.

223. The Office of Special Education has taken a somewhat equivocal position on the issue. See 2 [EHA Rulings] Educ. HandicAPPEd L. REP. (CRR) 211:19 (1978) (if state interprets psychotherapy as "medical service," local education agency is not obligated to provide such service since 34 C.F.R. $\S 300.13$ requires medical services for diagnostic and evaluative purposes only; if state interprets psychotherapy as "counseling services," services must be provided at no cost to parents if they are listed in IEP as related services); id. at 21 1:104-:105 (1979) (where state law permits "psychotherapy" to be provided by someone other than a psychiatrist and psychotherapy is needed to assist a handicapped child to benefit from special education, psychotherapy might be considered a "related service" under Department "related service" regulations). The Office of Civil Rights, during the same period, opined that psychiatric services must be provided, where appropriate, pursuant to section 504 of the Rehabilitation Act. See 3 [\$504 Rulings] Educ. Handicapped L. ReP. (CRR) 257:82 (1980); id. at 257:57,:191,:248 (1980).

224. 602 P.2d 157 (Mont. 1979). See also Papacoda v. Connecticut, 528 F. Supp. 68 (D. Conn. 1981); T.G. v. Board of Educ., 576 F. Supp. 420 (D.N.J. 1983), affd, 738 F.2d 425 (3d Cir. 1984); Max M. v. Thompson, 1984-85 Educ. Handicapped L. REP. (CRR) 556:227 (N.D. Ill. 1984) (psychotherapy provided by psychiatrist is related service, but services provided by social worker or other qualified non-physician provider are generally reimbursable costs).

225. 602 P.2d at 165 .

226. Id.

227. 568 F. Supp. 1340 (N.D. Ill. 1983). See also McKenzie v. Jefferson, 566 F. Supp. 404, 412 (D.D.C. 1983). 
psychiatric services provided in conjunction with the proposed placement because he concluded that such services were medical in character. The district court agreed with this interpretation. The court rejected the view that the services in question were psychological services for purposes of the EAHCA. ${ }^{228}$ In support of its position, the court cited the EAHCA regulations' definition of psychological services which does not list psychiatrists among the possible providers of such services. ${ }^{229}$ The court contended that psychiatrists are, by definition, licensed physicians. ${ }^{230}$ Therefore, intensive psychotherapy afforded by such providers should be deemed medical services. Since the psychotherapeutic services sought for Darlene L. were other than diagnostic or evaluative in purpose, the school system had no obligation to provide those services at public expense pursuant to the EAHCA. ${ }^{231}$

Resolution of this conflict in authority requires a three-part analysis. First, are psychotherapeutic services provided by or under the supervision of a psychiatrist "psychological services" for purposes of the Act? The statute provides no direct guidance on this question, but seems indirectly to suggest that the answer should be "yes." The "related services" definition refers to both "counseling" and "psychological services,"232 evidencing what appears to be an intent to encompass a broad spectrum of mental health services. Had Congress wished to exclude the most intensive types of mental health services from this range, it could have done so explicitly, as it did in excluding certain forms of medical services from the spectrum of related services available. Moreover, coverage of such intensive mental health services arises by implication as a result of the express coverage and protection of seriously emotionally disturbed children under the Act. ${ }^{233}$ It is questionable whether Congress would have included such children as beneficiaries of the legislation while at the same time limiting their access to the intensive services possibly needed for attaining any meaningful educational progress.

Second, are psychotherapeutic services provided by or under the supervision of a psychiatrist "medical services" within the terms of the statute? To the extent that intensive psychotherapeutic services can only be provided by a licensed psychiatrist or under a psychiatrist's supervision, the answer would seen to be "yes," in light of the Tatro decision discussed above. This class of services might include the prescription of drugs. In other cases, the answer should be "no." Counseling services available from social workers or psychologists who need not possess or be supervised by a person possessing a medical license are not generally regarded as medical in nature. Indeed, Congress specifically contemplated that the services of such persons would be

228. 568 F. Supp. 1340,1344 (N.D. Ill. 1983).

229. Id.

230. Id.

231. Id. at 1345 .

232. 20 U.S.C. $\S 1401(17)$ (1982).

233. See supra note 25. 
available under the EAHCA. ${ }^{234}$ The fact that a medically trained and licensed psychiatrist can also provide similar counseling services should not transform those services so as to render them "medical" in character when performed by nonmedical personnel. ${ }^{235}$ Instead, it suggests that psychiatrists performing certain counseling functions may themselves be providing services reasonably regarded as nonmedical in character, at least for purposes of the Act. It follows, in turn, that social workers or psychologists who work under the supervision of a psychiatrist are not necessarily supplying medical services, but may instead be functioning as adjunct providers of counseling services solely for purposes of convenience and cost control, rather than because oversight by a medically licensed psychiatrist is legally required with respect to all their activities. In a substantial number of cases, therefore, the provision of psychotherapeutic counseling services should not be regarded as medical in character and should therefore fall outside the medical services exception.

The final question, in any event, is whether the medical services proviso should be interpreted in isolation. If intensive psychotherapeutic services (including those services uniquely available from or under the supervision of a licensed psychiatrist) fall within the phrase "psychological services" but are excluded under the medical services proviso, it is necessary to determine how these two provisions are to be reconciled. Standard canons of statutory construction suggest that the more general reference to medical services should not lightly be adjudged to override the more specific treatment of psychological services. ${ }^{236}$ Moreover, a basic rule of construction assumes that each of several listed items should be afforded independent significance. ${ }^{237}$ This would only be the case if the "psychological services" provision is seen to stand on its own rather than narrowed consistent with the medical services proviso. Although the matter is plainly not free from doubt, ${ }^{238}$ the better reading of the EAHCA is that the full range of intensive psychotherapeutic services should not be regarded as medical services but should instead be treated, in appropriate cases, as psychological services requiring no special analysis beyond that discussed in Parts II through IV above. ${ }^{239}$ In effect, the

234. See S. REP. No. 168, 94th Cong., 1st Sess. 33 (1975); Irving Indep. School Dist. v. Tatro, 104 S. Ct. 3371,3378 (1984).

235. See T.G. v. Board of Educ., 576 F. Supp. 420, 424 (D.N.J. 1983).

236. Fourco Glass Co. v. Transmirra Products Corp., 353 U.S. 222 (1957).

237. See Reiter v. Sonotone Corp., 442 U.S. 330 (1979) (canons of construction suggest that terms connected by a disjunctive be given separate meaning unless context dictates otherwise); De Sylva v. Ballentine, 351 U.S. 570, 573 (1956) (word "or" is often used as a careless substitute for the word "and").

238. See Psychotherapy as a "Related Service," supra note 169.

239. To say that psychiatric services can in some instances be a related service for purposes of the Act is not, however, to conclude that psychiatric services are required by every handicapped child in every case. Under the Rowley decision discussed in part III supra, school districts would be obligated to provide such services only in those cases in which less intensive psychological services were insufficient to permit a child to benefit and make some progress toward appropriate educational goals. Thus, psychiatric services which go well beyond what is required for educational purposes do not fall within the scope of a school district's responsibilities under the EAHCA. 
medical services proviso should be seen as a partial, rather than comprehensive, exception to the EAHCA's related services definition, in order to honor Congress intent that children with severe emotional impairments have access to a full range of services needed to provide an equal educational opportunity.

In sum, the concept of equal educational opportunity can once again be employed as an aid to construing ambiguous provisions of the EAHCA. As demonstrated, notwithstanding Congress' explicit limitation on the availability of medical services, a de minimis limitation on that exception has been described by reference to the concept of equal educational opportunity. The concept also serves as a useful reminder that the medical services exception should be interpreted in the context of Congress' overall plan to ensure that all children, including seriously emotionally disturbed children in need of the full range of psychotherapeutic services, should receive those services needed to allow them to make at least minimal educational progress.

\section{VI}

\section{Conclusion}

This article has traced the major theme of equal educational opportunity as it bears upon educational programming decisions under the EAHCA. It has been argued that this complex theme is subject to numerous competing interpretations which must be carefully explored in each of the several settings in which the theme recurs. It has been suggested that the courts have relied upon the concept as an interpretive aid in addressing three important questions under the Act: in describing the level and extent of services to be provided handicapped children, in defining the scope of their educational needs, and in delineating the types of medical services available. Finally, the article has evaluated competing interpretations adopted in the judicial decisions which address these questions and has proposed alternative interpretations, where necessary, to give fuller effect to Congress' paramount objective-assisting state and local governments to meet the educational needs of handicapped children in order to assure equal protection of the law. 
